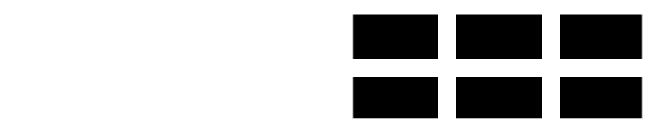

THE WILLIAM DAVIDSON INSTITUTE AT THE UNIVERSITY OF MICHIGAN BUSINESS SCHOOL

\title{
Dowry and Intrahousehold Bargaining: Evidence from China
}

\author{
By: Philip H. Brown
}

William Davidson Institute Working Paper Number 608

September 2003 


\title{
Dowry and Intrahousehold Bargaining: Evidence from China
}

\author{
Philip H. Brown ${ }^{\dagger}$
}

First draft: May 2002

This revision: August 2003

\begin{abstract}
This paper analyzes the relationship between a woman's intrahousehold bargaining position and her welfare within marriage. Simultaneity problems common to the literature are overcome by using dowry to proxy for bargaining position. Omitted variable bias is addressed by using grain shocks in the year preceding marriage and sibling sex composition as instruments for dowry. Instrumented dowry positively impacts several measures of a wife's welfare, including time allocation, household purchases, and the wife's decision-making authority, thereby offering strong evidence to support collective models of the household.
\end{abstract}

JEL Codes: D13, J12, J16, O12

Keywords: Intrahousehold Allocation, Dowry and Brideprice, Marriage, China

$\dagger$ Department of Economics, Colby College; phbrown@colby.edu.

The data collection for this paper was generously funded by the Ford Foundation. This paper has benefited from the insights and suggestions of David Lam, Albert Park, Jan Svejnar, and Bob Willis. I am also grateful for helpful comments from Claudio Agostini, Axel Anderson, Rachel Connelly, Cheryl Doss, Martin Farnham, Emma Hutchinson, Charlene Kalenkoski, Peter Katuschek, Laura Malaguzzi, Bill Parish, Vijayendra Rao, and seminar participants at University of Michigan, the 2002 Northeast Universities Development Consortium conference, and the 2002 RAND Economic Demography Workshop. 
The predominant model of household behavior formalized by Becker (1991) assumes that families maximize a single utility function, i.e., that either all household members have identical preferences or that one household member functions as a dictator, determining all allocations within the household. While this "unitary" model has provided important insights into household behavior, it offers little perspective on how individual preferences inform these allocations. More general models of the household that explicitly account for differences in preferences have resulted. One prominent set of models treats household decisions as the result of household members engaging in cooperative Nash bargaining (Manser and Brown, 1980; McElroy and Horney, 1981). In such "collective" approaches to household behavior, the bargaining position of household members plays an important role in determining resource allocations within the household.

While the concept of intrahousehold bargaining is theoretically straightforward, measuring bargaining position is difficult in practice; there is a paucity of socioeconomic data that include both plausible measures of household bargaining and individual welfare measures, and it has proven difficult to convincingly correct for endogeneity problems with existing data (Behrman, 1997). Nevertheless, numerous studies have been undertaken which find evidence supporting the collective models of households in many developing countries.

Due perhaps to intuitive appeal and empirical tractability, many studies focus on assignable income as relative measures of intrahousehold bargaining position, e.g., Folbre (1984), Von Braun (1988), Garcia (1990), and Hoddinott and Haddad (1995). They find grounds to reject the income pooling hypothesis central to the unitary model and find considerable evidence that control of resources has strong implications for how those resources are used by the household. However, by using income as a regressor, they unrealistically assume that labor supply decisions are exogenous. To avoid this simultaneity problem, other studies rely on nonlabor income to measure relative bargaining power, e.g., Schultz (1990) and Thomas (1990). This strategy is also problematic, however, because nonlabor income may depend on individuals being in a particular state, e.g., receiving benefits due to temporary illness, and because persistent unobservable differences in productivity and taste may have influenced past asset accumulation (Behrman, 1997). Furthermore, nonlabor income may reflect previous labor

\footnotetext{
${ }^{1}$ A more general model assumes only that household members allocate resources in a Pareto efficient manner (Chiappori, 1988; Chiappori, 1992).
} 
supply decisions and may thus be endogenous across the lifespan (Strauss and Thomas, 1995; Hoddinott, Alderman, and Haddad,1997; Schultz, 2001). ${ }^{2}$ An appealing alternative to income as an indicator of bargaining position are sex ratios at the relevant marriage ages, laws governing divorce, and other environmental factors that may shift threat points within marriage (Rao and Greene, 1993; Lundberg, Pollak, and Wales, 1997; Ward-Batts, 2001; Chiappori, Fortin, and Lacroix, 2002; Anderson, 2003). In principle, variation in such parameters can be used to identify how changing threat points affect household allocations. However, in the absence of randomized experiments, these factors may also be endogenous (Hoddinott et al., 1997).

In the search for exogenous determinants of intrahousehold bargaining position, one interesting recent approach has stressed the importance of assets controlled by individuals at the time of household formation. If such assets remain under control of the original holder, they may affect the relative bargaining positions in the household (and thus marital allocations) without the simultaneity concerns that arise in the previously described studies. Hence, Thomas, Contreras, and Frankenberg (1997) and Quisumbing and Maluccio (2003) find evidence that women's share of the assets brought to marriage by the spouses influences children's health and/or education outcomes in Indonesia, Bangladesh, Ethiopia, and South Africa. While concerns about simultaneity diminish when using pre-marital assets as a proxy for bargaining position, the possibility of omitted variable bias remains. Zhang and Chan (1999) thus implement a two-stage estimation strategy in which parental education is used as an instrument for dowry when estimating the effect of pre-marital endowments on the probability that husbands do household chores in Taiwan. However, unobservable characteristics of the wife, e.g., intelligence, may be correlated with both parental education and household bargaining outcomes, and the instrument may thus not be exogenous in the second stage. Further, they do not control for cohort differences, resulting in biased estimates if younger husbands both have more educated parents and contribute more time to housework. Their identification strategy is thus subject to endogeneity problems similar to those in many previous studies of household behavior.

This paper makes use of detailed new data from China to investigate the effect of dowry on household allocation in a cooperative Nash bargaining framework. To control for the

\footnotetext{
${ }^{2}$ Nevertheless, Schultz (2001) points out that there is a dearth of studies that systematically establish simultaneity bias between nonlabor income and household outcomes.
} 
potential endogeneity of marital payments, I use two types of instruments. The first is regional grain yield shocks in the year preceding marriage. The surveyed households are located in rural areas where livelihoods have long depended on farming. Unanticipated shocks to grain yield in the period just before marriage are therefore likely to have a substantial impact on household wealth accumulation, and thus on the ability of households to make transfers associated with marriage. The second type of instrument is the sibling sex composition of the bride and groom. Sibling sex composition likely affects the savings available for marital payments given the high costs associated with marrying sons versus the expected income from marrying daughters and the fact that credit markets are not well developed. These instruments influence payments made before marriage while remaining plausibly exogenous to household allocation decisions after marriage. In contrast to many other studies, I also include family background measures to better control for unobservable characteristics of the couple that may correlate with marital payments. In addition, estimates include marriage cohort dummies to account for the possibilities that the amount of marital payments reflect generational norms and that factors affecting intrahousehold decisions may vary by cohort. Finally, I use village fixed effects to control for unobserved heterogeneity. This identification strategy represents a significant improvement over previous studies in controlling effectively for potential bias from omitted variables and simultaneity.

I analyze the effect of dowry on a variety of household allocation decisions of interest to the wife, including her total leisure time, the time that her husband allocates to household chores, and the probability that the wife self-identifies as being satisfied with her life. To help distinguish between wealth effects and bargaining effects, I also analyze the impact of dowry on household spending on women's goods as a share of total expenditures, on the wife's share of the couple's total leisure time, on her husband's share of the couple's total time devoted to chores, and on the degree to which the wife has the authority to make decisions when the husband and wife disagree about household matters. I find that dowry has a positive and robust effect on each of these outcomes, providing strong evidence that pre-marital endowments affect household bargaining, and thus household consumption choices.

The remainder of the paper is organized as follows: section 2 reviews the collective Nash bargaining model; section 3 describes the role of marital payments in the marriage ritual in China; section 4 details the identification strategy used in the empirical investigation; section 5 
introduces the data used in the analysis; section 3 presents empirical evidence that dowry affects a wife's bargaining position; and section 7 concludes.

\section{Cooperative Nash Bargaining Model}

Following McElroy and Horney (1981), consider two unmarried individuals, $w$ and $h$, who each care about their own consumption of goods and leisure. Individual $i$ 's utility in the single state is given by $U_{s}^{i}=U_{s}^{i}\left(X^{i}\right)$, where $i \in\{w, h\}$, which is assumed to be nondecreasing and quasiconcave. Here, $X^{i} \in\left\{x^{i}, l^{i}\right\}, x^{i}$ is $i$ 's consumption of goods, and $l^{i}$ represents $i$ 's leisure. Suppose that $w$ has a private endowment given by $D$. In the single state, $w$ maximizes utility by choosing $X^{w}$ subject to the constraint given by $p x^{w}+r^{w} l^{w}=r^{w} T^{w}+D$ and $h$ maximizes utility by choosing $X^{h}$ subject to $p x^{h}+r^{h} l^{h}=r^{h} T^{h}$. Here, $p$ is the price of $x^{i}, r^{i}$ is $i$ 's wage rate, and $T^{i}$ is the total time available to $i$. This yields the strictly quasiconvex indirect utility functions $V^{w}\left(D, p, r^{w}, T^{w}\right)$ and $V^{h}\left(p, r^{h}, T^{h}\right)$, with the indirect utility of individual $w$ increasing in the endowment, $D$. That is, $d V^{w} / d D>0$. The indirect utilities outside of marriage correspond to the threat points of individuals within marriage (i.e., the minimum utility available to each individual in the event of marital dissolution), ${ }^{3}$ and thus to their relative intrahousehold bargaining positions.

In the cooperative Nash bargaining framework, $w$ and $h$ jointly choose consumption to maximize the gains from marriage over their own and their spouse's consumption:

$$
\left\lfloor U_{m}^{w}\left(X^{w}, X^{h}\right)-V^{w}\left(D, p, r^{w}, T^{w}\right)\right\rfloor\left\lfloor U_{m}^{h}\left(X^{w}, X^{h}\right)-V^{h}\left(p, r^{h}, T^{h}\right)\right\rfloor
$$

subject to the joint budget constraint equating total household expenditure to total household income:

$$
p x^{w}+p x^{h}+r^{w} l^{w}+r^{h} l^{h} \leq r^{w} T^{w}+r^{h} T^{h}+D
$$

\footnotetext{
${ }^{3}$ Lundberg and Pollack (1993) have shown that that the central predictions of the collective models of household behavior hold even when divorce is precluded in that couples may revert a noncooperative Nash equilibrium within marriage, i.e., the "separate spheres" solution.
} 
which is assumed to be binding. ${ }^{4}$ In the context of marriage, $D$ may be interpreted as dowry, and it is assumed that $D$ reverts to $w$ in case of divorce.

By the implicit function theorem, the solution to the household's problem is a system of demand equations for goods and leisure:

$$
\begin{aligned}
& X^{w}=f^{1}\left(D, p, r^{w}, T^{w}, r^{h}, T^{h}\right) \\
& X^{h}=f^{2}\left(D, p, r^{w}, T^{w}, r^{h}, T^{h}\right)
\end{aligned}
$$

The total effect of a change in dowry on the optimal allocation of $x$ and $l$ may be decomposed into a wealth effect, $\frac{\partial X^{i}}{\partial D}$, stemming from a shift in the budget constraint, and a bargaining effect, $\frac{\partial X^{i}}{\partial V^{w}} \frac{d V^{w}}{d D}$, resulting from a change in the relative marital threat points. That is,

$$
\frac{d X^{i}}{d D}=\frac{\partial X^{i}}{\partial D}+\frac{\partial X^{i}}{\partial V^{w}} \frac{d V^{w}}{d D}
$$

Holding the total budget constant, an increase in the relative bargaining position of one spouse must lower that of the other spouse. Thus, the net effect of a change in dowry has an ambiguous impact on $h$ 's consumption because the wealth and bargaining effects associated with dowry offset each other, i.e., $d X^{h} / d D><0$, assuming that each individual's consumption is a normal household good. However, the wealth and bargaining effects are both positive for $w$, i.e., $d X^{w} / d D>0$. As such, it is important to distinguish between bargaining and wealth effects before concluding that dowry shifts bargaining positions within marriage.

\section{Marital Transactions in Rural China}

Multiple transfers between the natal families characterize the marriage ritual in China. Brideprice (pinli or pinjin) is a transfer or series of transfers from the groom's parents to the bride's parents, while dowry (jiazhuang) represents a subsequent transfer from the bride's family

\footnotetext{
${ }^{4}$ The solution to this game is characterized by Pareto optimality in the allocation of resources, invariance with respect to linear transformations of each player's utility function, and independence of irrelevant alternatives. Manser and Brown (1980) discuss these implications.
} 
to the bride. Thatcher (1991) documents this system dating to the Spring and Autumn period of the Eastern Chou dynasty (770 - 256 B.C.), and it persisted through the first half of the $20^{\text {th }}$ century. However, the Chinese government sought to combat "feudal" practices in marriage with the founding of the People's Republic of China. Central to this objective was enacting the 1950 Marriage Law that specifically prohibited "the exaction of money or gifts in connection with marriage" (Meijer, 1971). Yet as Parish and Whyte (1978) put it, "Poor peasants were less enthusiastic about marriage struggle than they were about class struggle," and the new rules were largely ignored (Ocko, 1991; Min and Eades, 1995), particularly in rural areas.

In rural China, brideprice is negotiated between the two natal families, typically using a matchmaker as intermediary. ${ }^{5}$ Because the bride formally leaves her own family at marriage to join her husband's, the brideprice negotiation focuses on how the bride's family should be compensated for investments made in rearing the bride (Croll, 1981) and the loss of rights over her (Goody, 1973). A further consideration, particularly after agricultural decollectivization when families could again profit from the sale of excess production, is the loss of a bride's future productivity (Parish and Whyte, 1978; Min and Eades, 1995; Zhang, 2000). That is, brideprice is a mechanism for clearing the market, ${ }^{6}$ but not generally for making bequests to the husband or to the conjugal unit directly. A marriage date is also fixed at the time of betrothal, with engagement typically lasting one year (Liu, 2000). Brideprice is usually given to the bride's family in several installments over the course of the engagement. ${ }^{7}$

After brideprice is received, the bride's family decides the size and composition of the dowry; unlike brideprice, it is not subject to negotiation by the groom's parents. Offering elaborate dowries provides a vehicle for prestige building (Potter and Potter, 1990; Siu, 1993; Liu, 2000) and serves as an efficient pre-mortem inheritance (Parish and Whyte, 1978; Croll,

\footnotetext{
${ }^{5}$ Marriages that are arranged by the bride and groom themselves are increasingly common throughout China (Cheng, 1992). Interestingly, brideprice and dowry are paid even in the majority of these marriages (Parish and Whyte, 1978).

${ }^{6}$ It may be surprising that brideprice serves as the market clearing mechanism (as opposed to an analogous transfer from the bride's family to the groom's) because population growth and sex differences in age of marriage imply that the number of women exceeds the number of men in each marriage cohort (Rao, 1993 investigates a similar phenomenon in India). Possible explanations are that the benefits of marriage accrue disproportionately to husbands, that divorced men remarry while divorced women do not, or that there is greater male vis-à-vis female heterogeneity (Edlund, 1996). This puzzle remains an issue for further investigation in China.

${ }^{7}$ An alternative practice sometimes observed is the "exchange marriage" in which a sister of the groom marries a brother of the bride in lieu of formal brideprice. These marriages also tend to have lower dowries (Selden, 1993).
} 
1981). The difference in timing of inheritance for sons and daughters may be attributed to higher transaction costs for daughters who have married and left the household, and in many cases the local area. In much of rural China, current practice is that brides' parents retain part of the brideprice and pay out part as dowry. Dowry today typically includes bedding, clothing, furniture, and possibly other durables such as a bicycle, sewing machine, radio, and television (Siu, 1993; Liu, 2000). It also includes a significant cash component for the bride's exclusive use. Dowry thus forms the basis of the new conjugal unit's household. While the groom has equal access to the non-pecuniary aspects of dowry, the bride retains ultimate authority in its use (Zhang, 2000). For example, Yan (1996) describes brides using their dowries to make highinterest loans to in-laws who must pay brideprice in the marriage of a younger son.

Prior to 1981, divorce was legally difficult to obtain and the divorce rate was accordingly low. The 1981 Marriage Law considerably eased the requirements for divorce, however, and the rates have risen steadily since. In 1998 , there were 0.954 divorces per 1000 population (Wang, $2001){ }^{8}$ with the highest rates occurring in rural interior provinces (Zeng and $\mathrm{Wu}, 2000$ ). Furthermore, the 1981 Marriage Law stipulates that dowry reverts to the bride in the event of marital dissolution (Ocko, 1991). Divorce is therefore a realistic outside option for wives in the surveyed areas.

Given that brideprice is an intergenerational transfer from the groom's parents to the bride's parents and that dowry is an intergenerational pre-mortem bequest made by the bride's parents to the bride, it is expected that dowry affects bargaining position within marriage, while brideprice has no effect, as Zhang and Chan (1999) find in Taiwan. In what follows, I nevertheless test whether brideprice also affects marital allocations by including it as an additional regressor.

\section{Empirical Specification and Identification}

The wife's share of marital resources, $X^{w}$, resulting from the cooperative Nash bargaining process may be written as follows:

$$
X^{w}=\alpha_{1}+\beta_{1} D+\beta_{2} B+\mathbf{Z}_{1} \beta_{3}+e_{1}
$$

\footnotetext{
${ }^{8}$ For comparative purposes, the equivalent rate in the U.S. was 4.2 divorces per 1000 population in 1998 (Centers for Disease Control and Prevention, 1999).
} 
where $D$ is the dowry a wife brings to marriage, $B$ is the brideprice payment made to the bride's parents, and $\mathbf{Z}_{1}$ is a vector of demographic and explanatory variables including differences in the husband and wife's age and education levels, the number of children and adults (other than the husband and wife) in the household, household wealth, characteristics of the natal families, and marriage cohort and village dummies. Age differences (defined as the husband's age less the wife's) and education differences (defined analogously) may affect marital threat points. Household demographics may affect the distribution of household chores and the opportunity to engage in work outside the home. Household wealth (defined as the current value of household durables) may influence consumption choices. Characteristics of the natal household are included to control for unobserved characteristics of the conjugal couple that might correlate with marital payments. Marriage cohort dummies are included to control for generational differences in marital norms and the factors affecting intrahousehold decisions. These dummies were chosen to capture observed variation over time in both marital payments and household allocations, and vary by county. In addition, a set of cohort or village dummies are included to control for sex ratios, unemployment rates, and unobserved heterogeneity at the local level. ${ }^{9}$ If dowry affects the wife's consumption of goods or leisure, then $\beta_{1}$ will be positive.

Dowry and brideprice are unlikely to be exogenous in equation (5) because any unobserved characteristic of the wife that affects these payments may also affect her share of marital output. For example, Boulier and Rosenzweig (1984) show that physical attractiveness affects marital allocations, and it is plausible that it might also affect the size of the dowry transfer. Alternatively, women with very likable personalities may receive higher dowries from their parents and have better marital allocations than women with disagreeable personalities. In either case, estimating equation (5) using ordinary least squares (OLS) would produce biased and inconsistent estimates. Identification of equation (5) therefore requires instruments that are excludable from $\mathbf{Z}_{1}$. Dowry and brideprice may thus be estimated by:

$$
\begin{aligned}
& D=\alpha_{2}+\mathbf{Z}_{1} \delta_{1}+\mathbf{Z}_{2} \delta_{2}+\delta_{3} B+e_{2} \\
& B=\alpha_{3}+\mathbf{Z}_{1} \omega_{1}+\mathbf{Z}_{2} \omega_{2}+e_{3}
\end{aligned}
$$

\footnotetext{
${ }^{9}$ Ideally, dummies for the bride's and groom's home villages would both be used, but the former are not available in this survey. Still, marriages typically occur between households in neighboring villages or towns, and only rarely across long distances. Therefore, conditions in the two natal villages are likely to be similar.
} 
where $\mathbf{Z}_{2}$ is a vector of instrumental variables that explain $D$ and $B$ but which is independent of $X^{w}$

With incomplete credit markets in China's rural areas (Jalan and Ravallion, 1999), household savings are the primary source for marital payments. As a result, the instruments employed in this analysis each reflect savings available at the time of marriage. The first instrument is a measure of regional grain yield shocks - specifically, the deviation from trend in provincial per capita grain yield in the year immediately preceding marriage. Grain yield is a particularly important determinant of income (and thus savings) in rural western China where virtually all families are engaged in grain production, and this was even truer for the parents of the surveyed couples. The deviations from trend are the residuals from regressing historical per capita grain yield data in each province on a linear spline of harvest year; this identification strategy isolates the effect of transitory output shocks that are independent of time trends in the level of economic development in each locality. Because marriage typically occurs in the year following betrothal negotiations (Liu, 2000), grain shocks are lagged one year. The timing of marriage may be endogenously determined because families may seek to postpone entering marital negotiations until after a good harvest, especially in the absence of complete credit markets. The willingness to wait for a good harvest may nevertheless be tempered by cultural preferences for children marrying at certain ages. In any event, the groom's family is unlikely to permit delays to the wedding once a couple is betrothed and the wedding date has been fixed. ${ }^{10} \mathrm{I}$ find that negative regional grain shocks have a small negative influence on the number of marriages in the following year, but that the relationship is not significant (output omitted), suggesting that current wealth is not an overriding concern in deciding when to begin marriage negotiations.

The second instrument is the sibling sex composition of the bride and groom. Because brideprice exceeds dowry in most areas, the marriage of a daughter represents net household income while that of a son represents net household expenditures. Moreover, because these transfers tend to be substantial, the sex composition of children in the household is an important determinant of the lifetime wealth profile of Chinese families. Note that for this identification

\footnotetext{
${ }^{10}$ The groom's family is expected to give elaborate and expensive gifts to the bride's family during the length of the engagement, and a postponement increases the family's expenses (Yan, 1996). In addition, the bride will contribute to the groom's family's income, so there is an opportunity cost associated with delaying marriage.
} 
strategy to be successful, sibling sex composition cannot correlate with important unobservable characteristics of the individual. To that end, other family background factors such as parental education and the total number of siblings are included as additional controls. ${ }^{11}$

Given that the sex composition of children in the household is known, parents may anticipate future cash flows and adjust savings in order to smooth consumption over the lifetime. However, if preferences are time-inconsistent, i.e., if the household discount rate is hyperbolic (Angeletos, 2001; Harris and Laibson, 2001), then the sex composition of older children may play a larger role in determining dowry and brideprice than the sex composition of younger children given that Chinese children tend to marry in birth order. If, on the other hand, parents value future consumption more than current consumption, the sex composition of younger siblings may be more important. Finally, a prominent thought in the sociology and anthropology literatures is that while the sex composition of the groom's older siblings is a primary determinant of the size of the brideprice (Parish and Whyte, 1978; Siu, 1993), the sex composition of the bride's younger siblings is an overriding determinant of the size of the dowry (Min and Eades, 1985); this scenario is plausible because the brideprice payment is made before the dowry payment and because the former is typically larger than the latter, and suggests that rural Chinese parents may have difficulty smoothing consumption via savings.

Tables 1A and 1B present first-stage estimates for the determinants of dowry and brideprice, respectively, adjusted to 1985 prices. Column 1 presents the determinants of dowry and brideprice including exogenous shocks to grain yield as well as the sex composition of all siblings (suggesting time-consistent preferences with savings), column 2 substitutes the sex composition of older siblings (suggesting hyperbolic discounting), column 3 substitutes the sex composition of younger siblings (suggesting patience), and column 4 presents the determinants of marital payments when the groom's older siblings affect brideprice and the bride's younger siblings affect dowry (the scenario described in the sociology and anthropology literatures). Concurring with the observations of many social scientists conducting fieldwork in rural China, F-tests for the joint significance of the instruments show that the sex composition of the groom's older siblings and the bride's younger siblings are indeed strong determinants of marital

\footnotetext{
${ }^{11}$ If unobservables remain important after controlling for family characteristics, they might affect outcomes such as education in the same way that they affect marital allocation. I thus regressed the wife's education on family characteristics, birth year, province dummies, and sibling sex composition. I find that sibling sex composition does not have a significant effect on a wife's education.
} 
payments, and these are the instrumental variables used in the analysis that follows. ${ }^{12}$ Using Bassman's (1960) test, overidentification is rejected. These instruments are therefore used in the two-stage estimations that follow.

There are several concerns about the identification strategy that are worth noting. First, wealth may be simultaneously determined with household allocation. However, the only appropriate instrument available is the family's holding of high-quality flat (i.e., non-sloping and non-terraced) land - the preferred land for agricultural production. This instrument is plausibly exogenous from household decisions about the wife's consumption of goods, $x^{w}$, but not leisure, $l^{w}$, because a household's land holding is correlated with the time used to farm it. Wealth is therefore excluded from the empirical specifications wherein time is the outcome of interest. For completeness, I nevertheless included wealth as an additional regressor in these empirical specifications. I found that the point estimate for wealth is not significant and the other coefficients are not significantly different when it is included (output omitted).

Another concern is whether the effect of dowry persists after years of marriage. On the one hand, the cash component is likely to have been spent and the value of durables will have depreciated after a number of years, suggesting that dowry becomes less important. On the other hand, norms established early in the marriage may persist, so the effect of dowry on household allocations may endure. Indeed, I find that the estimated effect of dowry on certain aspects of a wife's welfare (such as her free time and the time that her husband allocates to household chores) is not significantly different for couples married for more than 10 years versus those married fewer than 10 years (output omitted). This finding suggests that the effects of dowry persist well into marriage. ${ }^{13}$

\footnotetext{
${ }^{12}$ I tried a variety of other instruments as well, including parent occupational status, historical data on land affected by natural disaster, and historical local grain yield data. However, none of these measures explains as much variation in dowry or brideprice as regional grain yield shocks and the sibling sex composition of the bride and groom. There is low variation in parent occupation, with only 1.7 percent of households not having at least one farmer. Historical natural disaster data has strong predictive power, but is unavailable for 1967-1977. Like disaster data, local grain yield is unavailable for several years; moreover, this variable has surprisingly little predictive power even when it is available. Indeed, even including these variables as additional instruments lowers the adjusted $\mathrm{R}^{2}$ in the first stage. A related issue is that wealthier households may be able to smooth consumption and thus be better insulated against income shocks (Foster, 1995 provides evidence for Bangladesh). In my sample, however, interacting the instruments with parent characteristics such as education and occupation provides no additional explanatory power.

${ }^{13}$ Future work will extend the analysis to account for dynamic bargaining models of the household such as that described by Lich-Tyler, 2001.
} 
It should also be noted that it is possible that dowry correlates with some other characteristic of the bride such as her social network, and that this trait is the true determinant of her marital bargaining position. To address this particular concern, I included measures of the bride's social network (e.g., whether family benefactors are related to the husband or wife and which families were visited during important holidays) as additional regressors in the empirical work that follows. I found that including these regressors had no discernable impact on the dowry coefficients (output omitted). ${ }^{14}$

A more general concern is whether the relationship between dowry and a wife's consumption works through her bargaining position rather than through a wealth effect. I thus analyze the effect of dowry on the wife's share of the couple's time allocation, on the household spending on assignable goods, and on the wife's decision-making authority when the husband and wife disagree. Differences in these outcomes stemming from differences in dowry suggest changes in the relative bargaining positions of the spouses, a story that is inconsistent with pure wealth effects (assuming, in the case of an individual's share of the couple's total leisure time, that any wealth effect is gender neutral). ${ }^{15}$ While the evidence I present suggests that dowry operates through a bargaining effect, I nevertheless cannot rule out other models that generate similar comparative statics.

\section{Data and Variables}

The second wave of the China Rural Poverty Survey, a collaborative effort of researchers from the Chinese Academy of Agricultural Science's Institute of Agricultural Economics and the University of Michigan (including the author), was conducted in February 2001. The survey covered four officially designated poor counties, with one county in each of four interior provinces: Gansu, Guizhou, Shaanxi, and Sichuan. ${ }^{16}$ The survey encompassed 587 households evenly distributed across 40 villages. Approximately two-thirds of the households also

\footnotetext{
14 The relative strength of the wife's social network was associated with each measure of wife's welfare, but never significantly so. Exploring this issue may be of interest for further study.

${ }^{15}$ If however, the wealth effect is not gender neutral, then wealth effects and bargaining effects are indistinguishable when looking at the shares of leisure accruing to each spouse. It is also possible that wife's leisure is a luxury good desired by both spouses. If so, then the wealth effect and bargaining effect may again be indistinguishable.

${ }^{16}$ The sampled county in Guizhou is a designated minority county with sizable Miao and Yi populations, but 80 percent of the sampled households in Guizhou are ethnic Han Chinese, making it difficult to distinguish differences between minority and non-minority households.
} 
participated in the first wave of the survey, conducted in December 1997. ${ }^{17}$ Excluding households in which the head is widowed, divorced, single, or absent reduces the sample to 460. I restrict the sample further by dropping 5 households that have key variables missing and 4 households in which marriage preceded the 1950 Marriage Law. The final sample thus consists of 451 couples married between 1950 and 2000, inclusive.

Respondents were asked detailed information about their marriages, including the values of dowry and brideprice. ${ }^{18}$ Detailed demographic and time allocation data were collected for all members of the household. Additionally, household expenditures on a range of goods were collected. Last, a separate instrument designed to assess attitudes, preferences, marital roles, and decision-making authority was asked of husbands and wives separately.

In this study, a wife's welfare within marriage is measured in the following ways:

1. the wife's total leisure (non-work) time;

2. the total time that husbands allocate to household chores;

3. the share of annual household accruing to women's goods;

4. the wife's self-reported satisfaction; and

5. the wife's decision-making authority

Again, dowry may have a wealth effect, a bargaining effect, or both. Spending on women's goods and the wife's decision-making authority help to distinguish between these effects. To further distinguish between wealth and bargaining effects, I also analyze the impact of dowry on the wife's share of the couple's total leisure time and on the husband's share of the couple's time devoted to chores; if wealth effects are gender neutral (admittedly, a strong assumption), then they cannot explain changes in the share of leisure time accruing to one of the partners.

These measures may require some explanation. Leisure time is defined as the time spent outside of market work, farm work, and household chores; although it excludes the wife's time allocated to gathering wood, cooking meals, cleaning, and several other chores, it may include unmeasured household activities such as time spent rearing children, sleeping, or not working

\footnotetext{
${ }^{17}$ Park and Ren (2001) and Brown and Park (2002) describe the first wave of the China Rural Poverty Survey.

${ }^{18}$ Detailed records of marital transactions are generally kept as part of the public record. When questioned, few respondents had difficulty recalling the exact amounts of their brideprice and dowry - or that of their siblings, children, or neighbors. Marital prices were converted to real values using 1985 as the base year. For marriages occurring prior to 1985 , prices were converted using the general retail price index, which was first calculated in 1950. For marriages occurring after the mid-1980s, prices were converted using the rural consumer price index, a more accurate reflection of rural prices that was introduced in 1985.
} 
because of illness. This measure therefore represents a wife's total potential leisure time (see Schultz, 2001 for discussion). Husbands' time allocated to chores is defined as the hours spent cooking, cleaning, and gathering firewood in an average week. To proxy for spending on women's goods, I use a category of spending called "ge ren yongpin zhichu" (expenditures on items of personal use), of which makeup, jewelry, and razors were given as examples. Because razors are inexpensive and durable, and thus likely contribute little to the total annual expenditure (unlike jewelry which is expensive or makeup which is consumed quickly), I attribute this consumption to the wife. ${ }^{19}$ This variable is measured as a share of total household spending. A wife's satisfaction is measured by the extent to which she agrees with the following statement, "Overall, I am satisfied with my life." This may be of interest because it may reflect welfare beyond the other outcomes evaluated here. It is reported as a categorical variable with values 1 ("completely unsatisfied"), 2 ("somewhat unsatisfied"), 3 ("somewhat satisfied"), and 4 (“completely satisfied"). ${ }^{20}$ Because few wives reported being either "completely unsatisfied" or "completely satisfied," the analysis will investigate only whether women report being satisfied or unsatisfied; this bivariate measure has the advantage of allowing IV probit estimation with corrected standard errors. Finally, the wife's decision-making authority is an index variable for which a value of 0 is assigned if the husband is responsible, 1 is assigned if the wife is responsible, and 0.5 is assigned if they are jointly responsible. Unlike decision-making authority which may simply reflect household specialization strategies (Thomas et al., 1997), this outcome measures the wife's empowerment to make decisions when there is a household dispute, a measure that is likely influenced by bargaining position directly. This question was asked separately of husbands and wives. In the few cases wherein the spouses disagreed, the wife's assessment is used in the analysis.

Basic indicators for the 451 sample households are presented in Table 2. On average, women spend 5 hours per day engaged in income-generating activities and household upkeep, leaving 19 hours per day for other activities, including leisure, sleeping, rearing children, and

\footnotetext{
${ }^{19}$ This interpretation is clearly problematic if many male goods are included in this expenditure category, but the results detailed below are difficult to explain if this is the case. In addition, similar (but slightly weaker) results are obtained when using the share of expenditures spent on children's clothing as the outcome variable of interest. This result is consistent with higher female bargaining power resulting in improved conditions for children, a common finding in the household bargaining literature, e.g., Thomas (1990).

${ }^{20}$ Importantly, data on the wife's satisfaction were collected when husbands and members of his natal family were not present.
} 
other activities. The distribution of leisure between husband and wife is roughly equal in the mean household, with women spending 4.0 percent less time in leisure than their husbands. ${ }^{21}$ Husbands spend 44 minutes per week cooking meals, cleaning, and gathering wood on average, although roughly half of the surveyed husbands do none of this work. The time that husbands spend helping with household chores amounts to 17.7 percent of the total time that couples devote to these activities, but 8.6 percent of husbands perform at least half of these chores. Spending on women's goods accounts for 0.2 percent of annual household spending on average, but this figure varies widely. Surveyed households commonly spend nothing on this form of consumption, while one percent of households spent 2 percent or more of their total expenditures on women's goods. Women were split nearly evenly between feeling satisfied and feeling unsatisfied with their lives. The majority of women reported feeling either "somewhat satisfied" or "somewhat unsatisfied," with only 13 women at either extreme. Finally, wives have sole decision-making authority when disputes arise in 27.0 percent of households, and shared responsibility in a further 16.0 percent of the surveyed households.

Turning to the independent variables, the average couple has been married for 19.4 years. The typical husband is 43 years old, 3 years older than his wife, and has completed primary schooling, 3 grades more than his wife. Households include 1.4 children and 0.6 other adults (typically an elderly parent) on average. Using 1985 as the base year, the real average household wealth as measured by the value of major durables was 655.9 yuan. Total parental education averages 2.4 years and husbands and wives have 3.8 and 2.7 siblings in their natal families, respectively. $^{22}$

The mean real brideprice was 538 yuan (in 1985 yuan) and the mean real dowry was 247 yuan, suggesting that the bride's family retains 54 percent of the brideprice received on average. Practice varies widely by province, however. In Gansu, dowry averages just 22 percent of brideprice, while average dowry exceeds brideprice by 18 percent in Sichuan (Figures 3.1A and

\footnotetext{
${ }^{21}$ Again, this measure excludes child rearing. The wife's share of leisure time may be misleading if wives spend more time caring for children than their husbands.

${ }^{22}$ Average family size in these areas fell considerably after the One Child Policy was adopted formally in 1979.
} 
3.1B). Further, dowry and brideprice have been appreciating at 3.8 percent and 4.6 in real terms, respectively, since $1950 .{ }^{23}$ The simple correlation between real dowry and brideprice is 0.43 .

\section{Empirical Results}

This section analyzes the effect of dowry on the wife's total leisure (non-work) time, the husband's time allocated to performing household chores, and the degree to which wives selfidentify as being satisfied with their lives. To help distinguish between wealth and bargaining effects, I also analyze the effect of dowry on the amount of money spent on women's goods as a share of annual household spending, on the wife's share of the couple's total leisure time and on the husband's share of the couple's total time allocated to household chores, and on the wife's decision-making authority when the spouses disagree about household issues. Per the discussion in section 3.4, I estimate the following fixed effects model for the effect of dowry on the wife's allocation, $X_{h v}^{w}$, in household $h$ in village $v$ :

$$
\begin{aligned}
X_{h v}^{w} & =\alpha+\beta_{1} D_{h v}+\beta_{2} B_{h v}+\beta_{3} A_{h v}+\beta_{4} E_{h v}+\beta_{5} N_{h v}^{k}+\beta_{6} N_{h v}^{a}+\beta_{7} W \\
& +\mathbf{F}_{h v} \beta_{8}+\sum_{c} \sum_{m} \lambda^{c m}+\gamma_{v}+e_{h v}
\end{aligned}
$$

where $D$ is the dowry she received at marriage, $B$ is the brideprice her parents received when she was betrothed, $A$ is the age difference between the husband and wife, $E$ is the difference in their education, $N^{k}$ is the number of children in the household, $N^{a}$ is the number of other adults in the household, $W$ is the household's wealth, $\mathbf{F}$ is a vector of natal family characteristics, and $\lambda^{c m}$ is a county - marriage cohort interaction term.

Table 3 shows the OLS, probit, and ordered probit estimates for several measures of the wife's allocation. Household wealth is omitted to save space, but including wealth does not appreciably change the signs or magnitudes of the other coefficients (output omitted). Column 1 presents OLS estimates for the wife's total leisure time, column 2 presents those for the husband's total time allocated to household chores, column 3 shows OLS estimates for women's

${ }^{23}$ Regressing dowry on marriage year yields highly significant, positive coefficients in each province. Regressing brideprice on marriage year produces highly significant, positive coefficients for Sichuan, Shaanxi, and Gansu. The effect in Guizhou is positive but not significant. 
goods as a share of household expenditures, column 4 presents the marginal effects for the probability that wives reports being satisfied (as opposed to unsatisfied) with their lives, and column 5 presents the marginal effects for the probability that women have some or full autonomy in making decisions when the husband and wife disagree about household issues using ordered probit estimation. The "shares" measures of husband and wife's time allocations are omitted to save space. County-marriage year interactions are included in order to control for time and location trends in marriage payments and household responsibilities. Also, village fixed effects are included in the first three estimates to control for unobserved heterogeneity at the local level. Because some survey forms were asked on a subsequent visit to the household during which some respondents were unavailable, there are fewer observations for the attitudinal outcomes. As a result of the smaller sample size and the fact that there exists no variation in these outcomes within some villages, county fixed effects supplant village fixed effects in estimating the determinants of these measures. ${ }^{24}$

With the exception of a husband's time allocated to household chores, dowry has a positive effect on a woman's welfare within marriage. Except for influencing a woman's decision-making authority, these effects are also significant. Dowry has a modest effect on a woman's leisure (non-work) time, with a 100 yuan increase (40 percent of the mean real dowry) increasing non-work time by 0.5 percent of the mean. The effect of dowry on the share of the household budget accruing to women's goods is more pronounced, with a 100 yuan increase in dowry corresponding to the mean budget share increasing by 12.6 percent. Similarly, higher dowry is associated with higher self-reported levels of satisfaction, with a 100 yuan increase in dowry at the mean resulting in an 8.9 percent higher probability of feeling satisfied. Again, the marginal effect of dowry on decision-making authority is not significant.

The estimated effects of brideprice are considerably smaller than those of dowry (except in determining the husband's time allocated to chores, although neither of these point estimates is significant) and are largely insignificant, consistent with the theory that brideprice should not affect marital welfare except via its effect on dowry. Brideprice has a significant, negative impact on household spending accruing to women's goods, suggesting perhaps that families that

\footnotetext{
${ }^{24}$ The difference in the sample size reported in columns 4 and 5 is attributable to the fact that there is no variation in wife's decision-making authority among the households in one marriage cohort in one county.
} 
pay higher brideprice negotiate lower consumption for the bride, but the magnitude is less than one-third that of dowry.

Other regressors enter largely as expected. When the difference in ages between husband and wife are greater, the wife's leisure time declines. Simple cross-tabulations suggest that relatively young wives do more manual labor, such as cleaning and gathering firewood (output omitted). Similarly, as the husband - wife education gap increases, the likelihood that the wife is less satisfied increases. The presence of other adults raises both a wife's satisfaction and the share of the household spending accruing to women's goods, which is sensible if these other adults are women. The wife's total number of siblings positively affects the time that husbands allocate to chores, perhaps because such women are used to sharing responsibility for household activities, while the husband's parents' education and his total number of siblings increase a wife's decision-making authority, perhaps because such men have more progressive attitudes or are used to sharing authority. Finally, the wife's parents' education has a positive effect on the time that husbands allocate to chores for reasons are not immediately clear.

As discussed above, dowry and brideprice may reflect unobserved characteristics of the bride and groom, and hence these estimates may be biased. For example, Boulier and Rosenzweig (1984) have shown that physical attractiveness affects allocations within marriage, and it is plausible that it might similarly impact the size of marital transfers. Similarly, a bride with a pleasant personality may receive a higher transfer from her parents and may also be treated well within her marriage. These unobserved positive characteristics of the bride will bias the estimated coefficients on dowry upward. By contrast, higher dowries may also result from unobservable negative characteristics of the groom and/or his family. That is, the bride's family may attempt to insure against poor treatment of their daughter in her conjugal home by influencing her intrahousehold bargaining position via a larger dowry. In such cases, the estimated coefficients on dowry are biased downward. ${ }^{25}$ Because the direction of the bias caused by omitted variables is ambiguous, whether dowry and brideprice have true effects on household allocations remains questionable.

Following the procedure described by Davidson and MacKinnon (1993), I test for the exogeneity of dowry and brideprice. Using the residuals from regressing dowry and brideprice

\footnotetext{
${ }^{25}$ It has been pointed out that negative aspects of the bride may also prompt a larger dowry in some cultures, but this may be less likely in the Chinese context because dowry is assignable and exclusive to the bride.
} 
on all of the exogenous variables in equations (5) and (6) as additional regressors when estimating equation (5), I test the hypothesis that the coefficients of the residuals are jointly zero. I find that the joint exogeneity of dowry and brideprice is rejected at the 99 percent confidence level (output omitted). Therefore, OLS is an inconsistent estimator and estimation using a twostage approach is warranted.

Dowry and brideprice are instrumented using regional grain shocks in the year preceding marriage and the sibling sex composition of the bride and groom, as detailed in section 4 . Because wealth may be simultaneous with household allocation decisions, I estimate the determinants of spending on women's goods, the wife's satisfaction, and the wife's decisionmaking authority when household disputes arise with and without controlling for wealth. When including wealth as an additional regressor, the household's allocation of high-quality, flat land is used as an instrument. However, I lack a satisfactory instrument when the outcome of interest is related to time allocation, so wealth is excluded in these regressions. As noted above, including un-instrumented wealth in these regressions nevertheless has no impact on the other estimated coefficients (output omitted).

Table 4 presents two-stage least squares estimates for the determinants of the wife's potential leisure time, defined as time spent outside of wage work, farm work, work in private business, and household chores. Column 1 presents estimates for leisure time in hours per day and column 2 presents estimates for the wife's share of the couple's total leisure time. Increasing dowry by 100 yuan increases the wife's potential leisure time by 44.4 minutes per day, or 3.9 percent of the mean. This effect is considerably larger than the OLS estimate presented in Table 3, suggesting that dowry correlates with unobserved negative characteristics of the groom more strongly than unobserved positive characteristics of the bride, per the above discussion. An alternative explanation is that dowry may be measured with considerable error. Given the cultural significance of this transfer, the fact that survey respondents rarely had difficulty recalling exact values, and the extent to which marital transactions are recorded in the public record, however, I find this explanation unlikely.

As noted in section 2, dowry may have a wealth effect, a bargaining effect, or both on the wife's potential leisure time. If there is only a wealth effect and if the wealth effect is gender neutral, the distribution of the couple's total leisure time should be unaffected by changes in dowry. However, dowry is associated with an increase in the percent of the couple's total leisure 
time accruing to the wife, with her share of leisure time increasing by 0.8 percentage points for a 100 yuan increase in dowry. Moreover, dowry has no discernable effect on a husband's total leisure time in separate regressions (output omitted), suggesting that a bargaining effect may offset a wealth effect associated with dowry. Controlling for dowry, brideprice has a weakly negative impact on a wife's leisure time, although the effect is not significant at the 0.10 level.

The determinants of the time that husbands allocate to cooking meals, cleaning, and gathering wood in an average week are presented in Table 5, both as a level (column 1) and as a share of the total time that the couple devotes to these activities (column 2). For every additional 100 yuan of dowry, husbands increase their time allocated to chores by 28.6 minutes on average, an increase of 64.4 percent. This finding is robust to the time spent on other household chores as well (output omitted). If dowry operates through a wealth effect alone, the time that husbands devote to household chores should fall; this finding to the contrary suggests that a bargaining effect overrides the wealth effect. Again, the magnitude of the effect is larger than that estimated using OLS, suggesting that the bride's family uses dowry as a means of insuring against unobserved negative characteristics of the groom and/or his family. Dowry also impacts the time share of household chores performed by husbands, ${ }^{26}$ with a 100 yuan increase in dowry resulting in an 11.2 percentage point increase in the share of household chores performed by men. This finding is also consistent with the notion that dowry has a bargaining effect, assuming again that wealth effects are gender neutral. Larger age gaps are associated with the husband doing a greater share of the household chores, as is the size of the wife's natal family.

The determinants of women's goods as a share of household expenditures are presented in Table 6. Two specifications are estimated, the first excluding wealth (column 1), the second including it (column 2). The coefficient for instrumented wealth is not significant, and including this measure does not dramatically alter the point estimates for dowry or brideprice. Increasing dowry by 100 yuan corresponds to increasing the expenditure share of women's goods by 0.08 percentage points, or 45.6 percent of the average expenditure. Moreover, regressing the share of

\footnotetext{
${ }^{26}$ Men are reported as doing all of these chores in 5 percent of the sampled households. One explanation is that husbands do all of the household chores when wives are chronically sick. Health information including the frequency and duration of sickness is available for two-thirds of these households. In this subsample, the wife selfreported no sickness in the previous year in 47 percent of households. Only one woman reported being sick for more than a month, and none reported being sick for more than 5 weeks. An alternative hypothesis is that men specialize in performing these chores in some households. Dropping these households from the sample reduces the point estimate by 23 percent and the effect remains significant.
} 
household spending allocated to alcohol and tobacco (goods consumed exclusively by men in the survey areas) on dowry and brideprice does not yield significant estimates (output omitted). These findings provide further evidence that dowry works through a bargaining effect. Additionally, having more adults in the household is associated with higher spending on women's goods, presumably because some of the additional adults are women. As before, the magnitudes of the point estimates are smaller than those estimated using OLS.

Table 7 shows the marginal effects of the determinants of women's satisfaction using IV probit estimation. Standard errors are corrected following the procedure described in Maddala (1983) and Newey (1987). As noted above, there are fewer observations for the attitudinal outcomes, and limited variation in some villages renders including village fixed effects impossible. Thus, county fixed effects replace village fixed effects in the remaining estimations. Column 1 presents estimates when wealth is excluded from the specification and column 2 presents those when wealth is included. The point estimates for dowry are 22.9 percent lower when wealth is included, providing evidence that the wealth effect is important. Still, the coefficient is positive and significant even when controlling for wealth, again suggesting that there is a bargaining effect at play. As dowry increases by 100 yuan, women are 12 to 16 percent more likely to report being satisfied with their lives. Women report higher satisfaction when there are other adults in the home, but neither brideprice nor the other regressors has a discernable effect on wife's satisfaction. Once again, the point estimates are larger than those obtained from OLS estimation, supporting the notion that dowry compensates for negative characteristics of the groom and/or his family.

Wife's decision-making authority is an index variable that describes whether women have no authority, complete authority, or joint authority with their husbands to make decisions when spouses disagree about household matters. Joint decision-making authority occurs in 16.0 percent of households and may be an important reflection of bargaining power. Estimates from the two-stage ordered probit model are thus shown in Table 8, columns 1 and 2. Because the asymptotic variance-covariance matrix has not been derived for this model, however, the standard errors have not been corrected and the $\mathrm{z}$ statistics that are shown are unreliable. Point estimates nevertheless suggest that a wife's dowry has a strong influence on her decision-making authority, and that this finding is robust to the inclusion of household wealth, again suggesting 
that dowry operates through a bargaining effect. The estimated effect of brideprice is negative, as above, and much smaller than that of dowry.

Aggregating wives who have no decision-making authority with those who have joint decision-making authority permits estimation of an IV probit model with corrected standard errors (Maddala, 1983; Newey, 1987), shown in columns 3 and 4. Again, dowry has a positive and significant impact on a wife's decision-making authority. Controlling for household wealth reduces the point estimate of dowry by 20.5 percent, but the effect remains significant. That dowry influences a wife's decision-making authority and that it does so independently of household wealth lend further credence to the notion that dowry affects a wife's intrahousehold bargaining position. Neither brideprice nor wealth has a significant effect on a wife's decisionmaking authority. Finally, the point estimate for instrumented dowry is larger than that of uninstrumented dowry, again suggesting that dowry correlates with negative characteristics of the groom and/or his family, i.e., that the OLS estimates are biased downward.

All of these results show a consistently negative (if insignificant) effect of brideprice on a wife's welfare. If brideprice only acts as a price mechanism, then it is unclear why it should have any impact on marital outcomes once dowry is controlled for. However, it appears that families who pay higher brideprices may compensate by extracting more labor or negotiating lower consumption for brides. In the cooperative Nash bargaining context, it is possible that this outcome is achieved by making unmeasured, private transfers to sons in order to raise their marital threat points, but this hypothesis cannot be confirmed with these data.

\section{Conclusion}

Theory predicts that individual control of resources affects one's bargaining position within marriage and thus one's allocation of marital output. While the concept of bargaining position is straightforward, measuring it for empirical investigation has proven difficult. Labor income, nonlabor income, and extrahousehold environmental parameters each may suffer from simultaneity bias in the absence of strong identifying assumptions. An interesting alternative indicator of bargaining position is individual endowments brought to the marriage, such as dowry. However, previous studies focusing on the impact of these transfers on welfare within marriage have not sufficiently controlled for omitted variable bias. 
In the Chinese context, brideprice serves as a market clearing price by compensating a woman's family for human capital investments made during the woman's childhood (Croll, 1981), for the loss of rights over her (Goody, 1973), and for the loss of her future contribution to household income (Parish and Whyte, 1978; Min and Eades, 1995; Zhang, 2000). Dowry, on the other hand, is an intergenerational transfer that serves primarily as a pre-mortem bequest to a daughter (Parish and Whyte, 1978; Croll, 1981). Because the wife controls dowry and because she retains this authority even in the event of divorce (a realistic option in rural China), dowry may serve as a proxy for a woman's bargaining position.

This paper makes use of new data from rural China to investigate the impact of dowry on several measures of intrahousehold allocation in a cooperative Nash bargaining framework. To control for the potential endogeneity of marital payments, I use two types of instruments that reflect household savings available for marital payments. The first is regional grain shocks in the year preceding marriage. Agriculture shocks are likely to have large effects on savings in rural communities in which credit markets are incomplete and in which the population consists almost entirely of farmers, and thus on the ability of households to pay dowry or brideprice. The second instrument is the sibling sex composition of the bride and groom. Because dowry payments are generally smaller than brideprice payments in the surveyed areas, the marriage of daughters represents net household income while that of sons represents net household expenditures. Hence, the sex composition of children impacts the resources available to the family for making marital payments. I control for unobservable correlates of sibling sex composition by including family characteristics as additional regressors. All estimates also include marriage cohort dummies to control for generational norms in household allocation. Furthermore, the empirical specifications are estimated with village fixed effects to control for unobserved heterogeneity. This identification strategy represents a significant improvement over previous studies in controlling effectively for potential bias from omitted variables and simultaneity.

I find that dowry has a positive and robust impact on the wife's leisure time, on the amount of time that husbands allocate to performing household chores each week, and on the probability that the wife self-identifies as being satisfied with her life. To better discern between wealth effects and bargaining effects associated with dowry, I also analyze the effect of dowry on spending on women's goods as a share of the total household expenditures, on the wife's share of the couple's total leisure time, and on the husband's share of the couple's time allocated 
to performing household chores. Dowry has a positive and significant effect on each of these outcomes, and changes in the distribution of goods and time within the household are difficult to explain if dowry only has a wealth effect. Finally, I investigate the effect of dowry on a wife's decision-making authority when the husband and wife disagree about matters of importance to the household. Dowry has a positive and significant effect, again suggesting that dowry affects the wife's bargaining position.

These results provide strong empirical support for the theoretical literature linking control of resources to intrahousehold allocation decisions, and thus to the collective models of the household. Based on the robustness of these findings, it is plausible that dowry serves as a vehicle for altruistic parents to improve their daughter's marital welfare in addition to being a pre-mortem inheritance. Better understanding the motivation for giving dowry and the determinants of dowry size remain priorities for further research. 
William Davidson Institute Working Paper 608

\section{References}

Anderson, S. (2003). "Why Dowry Payments Declined with Modernization in Europe but Are Rising in India." Journal of Political Economy. 111(2): 269-310.

Angeletos, G.M. (2001). “The Hyperbolic Consumption Model: Calibration, Simulation, and Empirical Evaluation.” Journal of Economic Perspectives. 15(3): 47-68.

Bassman, R.L. (1960). "On Finite Sample Distributions of Generalized Classical Linear Identifiability Test Statistics." Journal of the American Statistical Association. 55(292): 650-659.

Becker, G. (1991). A Treatise on the Family. Enlarged Edition. Cambridge, MA: Harvard University Press.

Behrman, J.R. (1997). "Intrahousehold Distribution and the Family.” In Rosenzweig, M.R. and Stark, O., eds., Handbook of Family and Population Economics. Amsterdam: Elsevier Science B.V., 125-187.

Boulier, B.L. and Rosenzweig, M.R. (1984). "Schooling, Search, and Spouse Selection: Testing Economic Theories of Marriage and Household Behavior." Journal of Political Economy. 92(4): 712-732.

Brown, P.H. and Park, A. (2002). "Education and Poverty in Rural China.” Economics of Education Review. 21(6): 523-541.

Centers for Disease Control and Prevention. (1999). National Vital Statistics Reports. 47(21): 14.

Cheng, D. (1992). "Nongcun Funu Zeou Wenti Diaocha (An Investigation into Spousal Choice Among Rural Women).” Renkou yu Jingji. (1): 44-49.

Chiappori, P.-A. (1988). "Rational Household Labor Supply.” Econometrica. 56(1): 63-89. . (1992). “Collective Labor Supply and Welfare." Journal of Political Economy. 100(3): 437-467.

Chiappori, P.-A., Fortin, B., and Lacroix, G. (2002). "Marriage Market, Divorce Legislation, and Household Labor Supply.” Journal of Political Economy. 110(1): 37-72.

Croll, E. (1981). The Politics of Marriage in Contemporary China. Cambridge: Cambridge University Press.

Davidson, R. and MacKinnon, J.G. (1993). Estimation and Inference in Econometrics. New York: Oxford University Press.

Edlund, L. (1996). "Dear Son - Expensive Daughter: Why do Scarce Women Pay to Marry?" Mimeo, Stockholm School of Economics. 
Folbre, N. (1984). "Market Opportunities, Genetic Endowments, and Intrafamily Resource Distribution: Comment." American Economics Review. 74(3): 518-520.

Foster, A.D. (1995). "Prices, Credit Markets, and Child Growth in Low Income Rural Areas." Economic Journal. 105(430): 551-570.

Garcia, M. (1990). "Resource Allocation and Household Welfare: A Study of Personal Sources of Income on Food Consumption, Nutrition, and Health in the Philippines." Mimeo, Institute of Social Sciences, The Hague.

Goody, J. (1973). "Bridewealth and Dowry in Africa and Eurasia." In Goody, J. and Tambiah, S.J., Bridewealth and Dowry. Cambridge: Cambridge University Press, 1-58.

Harris, C. and Laibson, D. (2001). "Dynamic Choices of Hyperbolic Consumers." Econometrica. 69(4): 935-957.

Hoddinott, J., Alderman, H., and Haddad, L. (1997). “Testing Competing Models of Intrahousehold Allocation.” In Haddad, L., Hoddinott, J., and Alderman, H., eds., Intrahousehold Resource Allocation in Developing Countries: Models, Methods, and Policy. Baltimore: Johns Hopkins University Press, 129-141.

Hoddinott, J. and Haddad, L. (1995). Women's Income and Boy - Girl Anthropometric Status in Côte d'Ivoire. World Development. 22(4): 543-553.

Jalan, J. and Ravallion, M. (1999). “Are the Poor Less Well Insured? Evidence on Vulnerability to Income Risk in Rural China.” Journal of Development Economics. 58(1): 61-81.

Lich-Tyler, S. (2002). "Negotiations and Love Songs: The Dynamics of Bargained Household Decisions." Mimeo, University of Michigan.

Liu, X. (2000). In One's Own Shadow: An Ethnographic Account of the Condition of PostReform China. Berkeley: University of California Press.

Lundberg, S. and Pollack, R.A. (1993). "A Separate Spheres Bargaining and Marriage Market." Journal of Political Economy. 101(6): 988-1010.

Lundberg, S., Pollack, R., and Wales, T.J. (1997). "Do Husbands and Wives Pool Their Resources? Evidence from the United Kingdom Child Benefit." Journal of Human Resources. 32(3): 463-480.

Maddala, G. (1983). Limited-Dependent and Qualitative Variables in Econometrics. Cambridge: Cambridge University Press.

Manser, M. and Brown, M. (1980). "Marriage and Household Decision-Making: A Bargaining Analysis." International Economic Review. 21(2): 31-44. 
McElroy, M.B. and Horney, M.J. (1981). "Nash-Bargained Household Decisions: Toward a Generalization of the Theory of Demand." International Economic Review. 22(6): 333350 .

Meijer, M.J. (1971). Marriage Law and Policy in the People's Republic of China. Hong Kong: Hong Kong University Press.

Min, H. and Eades, J.S. (1995). "Brides, Bachelors, and Brokers: The Marriage Market in Rural Anhui in an Era of Economic Reform." Modern Asian Studies. 29(4): 841-869.

Newey, W. (1987). "Simultaneous Estimation of Limited Dependent Variable Models with Endogenous Explanatory Variables." Journal of Econometrics. 36(3): 231-250.

Ocko, J.K. (1991) "Women, Property, and Law in the People's Republic of China." In Watson, R.S. and Ebrey, P.B., eds., Marriage and Inequality in Chinese Society. Berkeley: University of California Press, 313-346.

Parish, W.L. and Whyte, M.K. (1978). Village and Family Life in Contemporary China. Chicago: University of Chicago Press.

Park, A. and Ren, C. (2001). "Microfinance with Chinese Characteristics." World Development. 29(1): 39-62.

Potter, S.H. and Potter, J.M. (1990). China's Peasants: The Anthropology of a Revolution. Cambridge: Cambridge University Press.

Quisumbing, A.R. and Maluccio, J.A. (2003). "Resources at Marriage and Intrahousehold Allocation: Evidence from Bangladesh, Ethiopia, Indonesia, and South Africa." Oxford Bulleting of Economics and Statistics. Forthcoming.

Rao. V. (1993). “The Rising Price of Husbands: A Hedonic Analysis of Dowry Increases in Rural India.” Journal of Public Economy. 101(4): 666-677.

Rao, V.J. and Greene, M. (1993). "Marital Instability, Intrahousehold Bargaining, and their Implication for Fertility in Brazil.” Mimeo, Population Research Center, University of Chicago.

Schultz, T.P. (1990). "Testing the Neoclassical Model of Family Labor Supply and Fertility." Journal of Human Resources. 25(4): 599-634.

. (2001). "Women's Role in the Agricultural Household: Bargaining and Human Capital." In Gardner, B.L. and Rausser, G.C., eds., Handbook of Agricultural Economics. Amsterdam: Elsevier Science, B.V., 383-456. 
Selden, M. (1993). "Family Strategies and Structures in Rural North China." In Davis, D. and Harrell, S., eds., Chinese Families in the Post-Mao Era. Berkeley: University of California Press, 139-164.

Siu, H.F. (1993). "Reconstituting Dowry and Brideprice in South China.” In Davis, D. and Harrell, S., eds., Chinese Families in the Post-Mao Era. Berkeley: University of California Press, 165-188.

Strauss, J. and Thomas, D. (1995). "Human Resources: Empirical Modeling of Household and Family Decisions." In Behrman, J. and Srinivasan, T.N., eds., Handbook of Development Economics, Volume III. Amsterdam: Elsevier Science B.V., 1883-2023.

Thatcher, M.P. (1991). "Marriages of the Ruling Elite in the Spring and Autumn Period." In Watson, R.S. and Ebrey, P.B., Marriage and Inequality in Chinese Society. Berkeley: University of California Press, 25-58.

Thomas, D. (1990). "Intra-household Resource Allocation: An Inferential Approach.” Journal of Human Resources. 25(4): 635-664.

Thomas, D., Contreras, D., and Frankenberg, E. (1997). "Distribution of Power Within the Household and Child Wealth.” Mimeo, Rand Corporation, Santa Monica.

Von Braun, J. (1988). "Effects of Technological Change in Agriculture on Food Consumption and Nutrition: Rice in a West African Setting." World Development. 16(9): 1083-1098.

Wang, Q. (2001). "China's Divorce Trends in the Transition toward a Market Economy." Journal of Divorce and Remarriage. 35(102): 173-189.

Ward-Batts, J. (2001). "Out of the Wallet and into the Purse: Modeling Family Expenditures to Test Income Pooling.” Population Studies Center Research Report 01-466, University of Michigan.

Yan, Y. (1996). The Flow of Gifts: Reciprocity and Social Networks in a Chinese Village. Stanford, CA: Stanford University Press.

Zeng, Y. and Wu, D. (2000). "Regional Analysis of Divorce in China since 1980." Demography. 37(2): 215-219.

Zhang, J. and Chan, W. (1999). "Dowry and Wife's Welfare: A Theoretical and Empirical Analysis.” Journal of Political Economy. 107(4): 786-808.

Zhang, W. (2000). "Dynamics of Marriage in Chinese Rural Society in Transition: A Study of a Northern Chinese Village." Population Studies. 54(1): 57-69. 
William Davidson Institute Working Paper 608

Figure 1A. Mean Value of Marital Transactions (Sichuan and Guizhou)

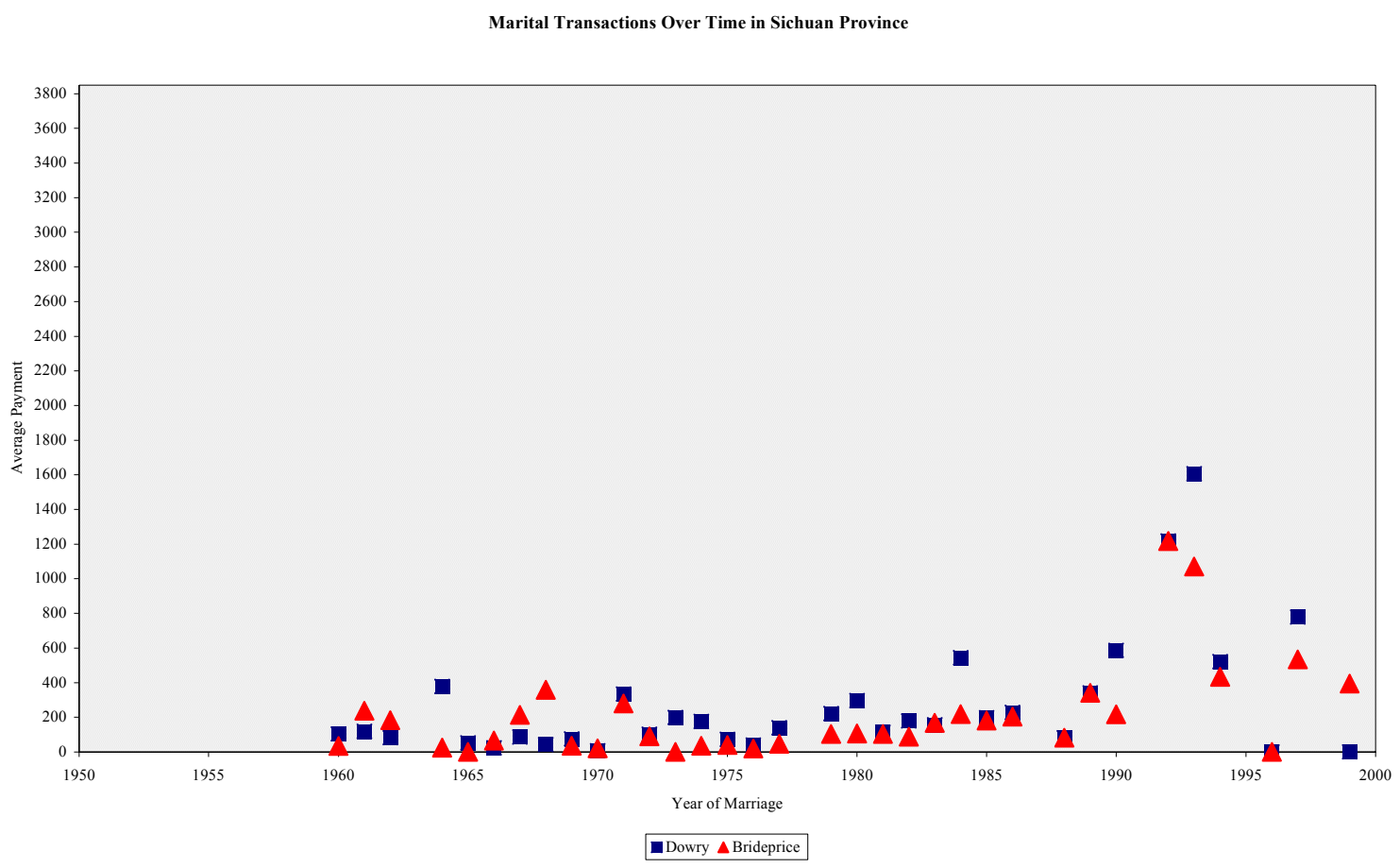

Marital Transactions Over Time in Guizhou Province

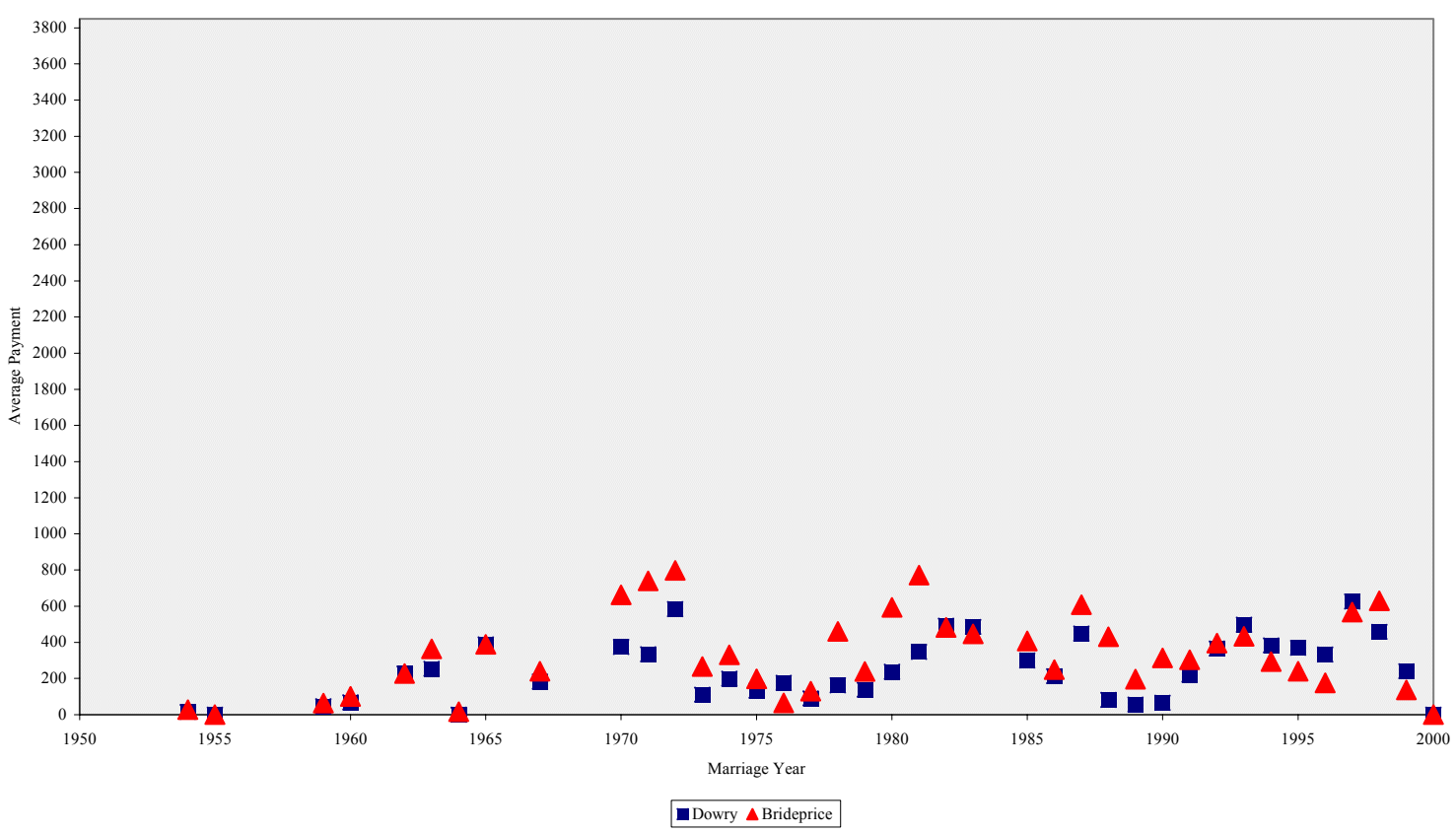


William Davidson Institute Working Paper 608

Figure 1B. Mean Value of Marital Transactions (Gansu and Shaanxi)

Marital Transactions Over Time in Shaanxi Province

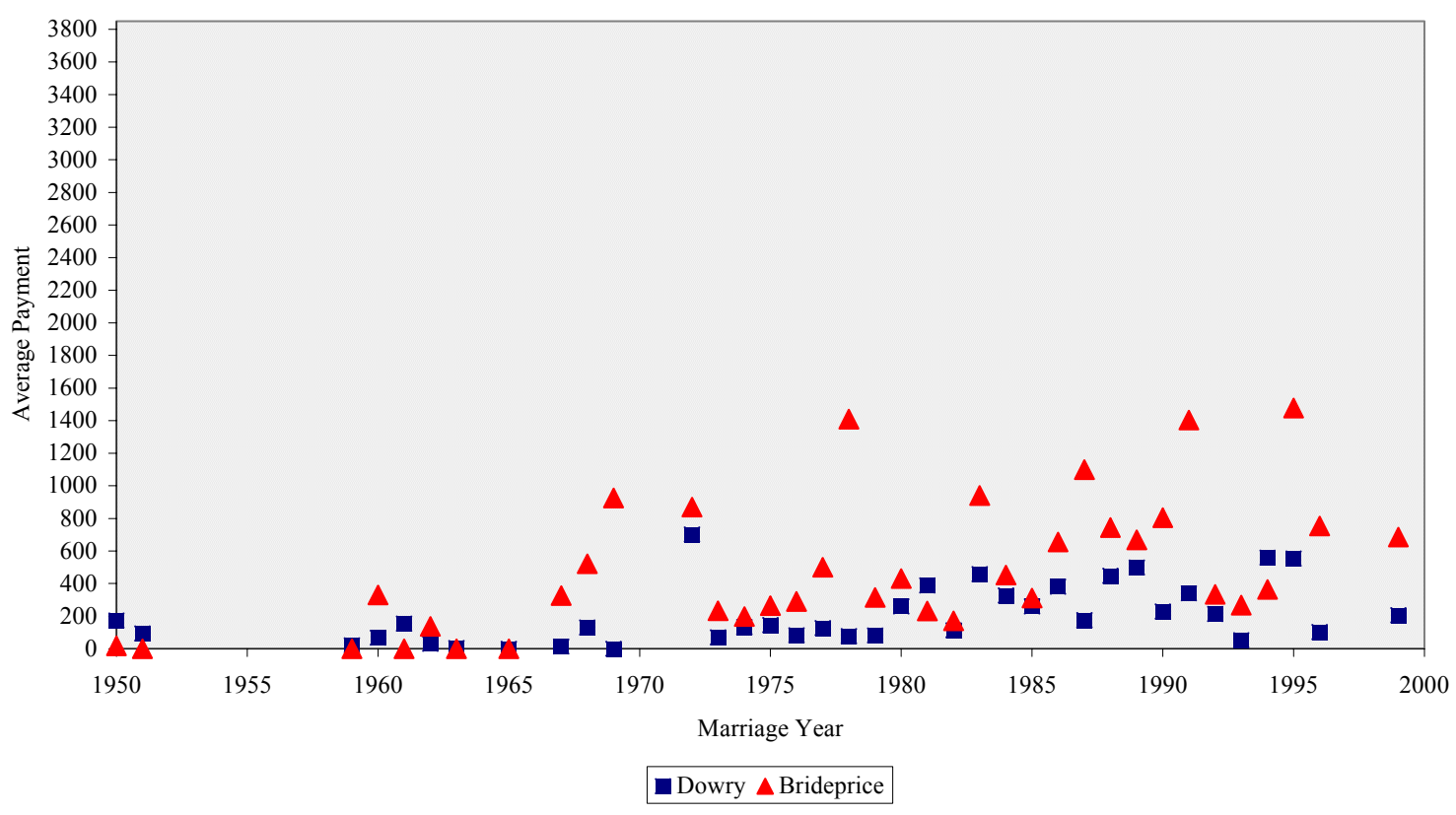

Marital Transactions Over Time in Gansu Province

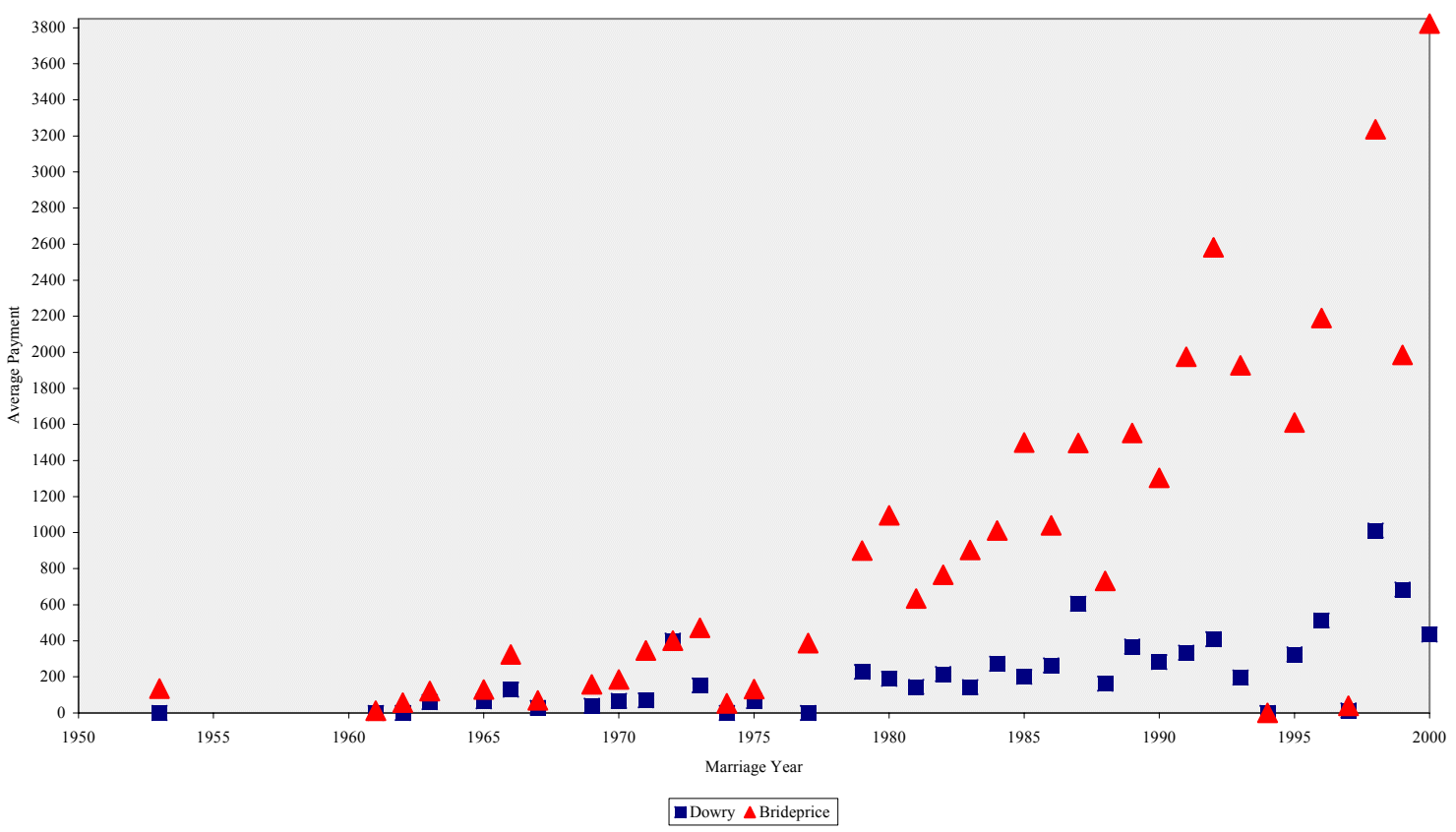




\section{Table 1A: Determinants of Dowry (OLS)}

\begin{tabular}{|c|c|c|c|c|c|}
\hline Variable & Unit & (1) & (2) & (3) & (4) \\
\hline grain shock 1 year before marriage & $\mathrm{kg} /$ person & $\begin{array}{l}1.628 * * * \\
(2.66)\end{array}$ & $\begin{array}{l}1.715^{* * *} \\
(2.78)\end{array}$ & $\begin{array}{l}1.703 * * * \\
(2.79)\end{array}$ & $\begin{array}{l}1.709 * * * \\
(2.81)\end{array}$ \\
\hline sex composition of wife's sibs & difference & $\begin{array}{l}24.442 * * * \\
(2.70)\end{array}$ & & & \\
\hline sex composition of husband's sibs & difference & $\begin{array}{l}8.328 \\
(1.10)\end{array}$ & & & \\
\hline sex comp of wife's older sibs & difference & & $\begin{array}{l}2.964 \\
(0.27)\end{array}$ & & \\
\hline sex comp of husband's older sibs & difference & & $\begin{array}{l}18.421^{*} \\
(1.77)\end{array}$ & & $\begin{array}{l}15.494 \\
(1.51)\end{array}$ \\
\hline sex comp of wife's younger sibs & difference & & & $\begin{array}{l}37.437 * * * \\
(3.09)\end{array}$ & $\begin{array}{l}35.872 * * * \\
(2.96)\end{array}$ \\
\hline sex comp of husband's younger sibs & difference & & & $\begin{array}{l}-0.373 \\
(0.04)\end{array}$ & \\
\hline age difference & years & $\begin{array}{l}-7.032 \\
(1.54)\end{array}$ & $\begin{array}{l}-7.983 * \\
(1.75)\end{array}$ & $\begin{array}{l}-7.649^{*} \\
(1.67)\end{array}$ & $\begin{array}{l}-7.378 \\
(1.63)\end{array}$ \\
\hline education difference & grades & $\begin{array}{l}-3.905 \\
(1.00)\end{array}$ & $\begin{array}{l}-3.919 \\
(1.00)\end{array}$ & $\begin{array}{l}-2.833 \\
(0.73)\end{array}$ & $\begin{array}{l}-3.408 \\
(0.88)\end{array}$ \\
\hline children in home & \# & $\begin{array}{l}32.150^{* *} \\
(2.23)\end{array}$ & $\begin{array}{l}33.221^{* *} \\
(2.29)\end{array}$ & $\begin{array}{l}31.656^{* *} \\
(2.20)\end{array}$ & $\begin{array}{l}30.797 * * \\
(2.15)\end{array}$ \\
\hline other adults in home & \# & $\begin{array}{l}-2.167 \\
(0.13)\end{array}$ & $\begin{array}{l}-0.564 \\
(0.03)\end{array}$ & $\begin{array}{l}-1.260 \\
(0.07)\end{array}$ & $\begin{array}{l}-2.534 \\
(0.15)\end{array}$ \\
\hline wife's parents' ed & years & $\begin{array}{l}5.748 \\
(0.57)\end{array}$ & $\begin{array}{l}17.450 * \\
(1.79)\end{array}$ & $\begin{array}{l}15.512 \\
(1.41)\end{array}$ & $\begin{array}{l}15.384 \\
(1.41)\end{array}$ \\
\hline husband's parents' ed & years & $\begin{array}{l}17.238 \\
(1.58)\end{array}$ & $\begin{array}{l}19.647^{*} \\
(1.90)\end{array}$ & $\begin{array}{l}4.327 \\
(0.43)\end{array}$ & $\begin{array}{l}4.566 \\
(0.45)\end{array}$ \\
\hline wife's total siblings & \# & $\begin{array}{l}0.752 \\
(0.09)\end{array}$ & $\begin{array}{l}-0.944 \\
(0.11)\end{array}$ & $\begin{array}{l}2.045 \\
(0.24)\end{array}$ & $\begin{array}{l}0.886 \\
(0.10)\end{array}$ \\
\hline husband's total siblings & \# & $\begin{array}{l}2.945 \\
(0.34)\end{array}$ & $\begin{array}{l}2.933 \\
(0.33)\end{array}$ & $\begin{array}{l}3.109 \\
(0.36)\end{array}$ & $\begin{array}{l}3.145 \\
(0.36)\end{array}$ \\
\hline Constant & & $\begin{array}{l}240.315^{* * * *} \\
(3.66)\end{array}$ & $\begin{array}{l}235.443 * * * \\
(3.55)\end{array}$ & $\begin{array}{l}241.273^{* * *} \\
(3.68)\end{array}$ & $\begin{array}{l}247.216^{* * * *} \\
(3.78)\end{array}$ \\
\hline $\begin{array}{l}\text { Village FE } \\
\text { County FE }\end{array}$ & & yes & yes & yes & yes \\
\hline Observations & & 451 & 451 & 451 & 451 \\
\hline R-squared & & 0.296 & 0.286 & 0.297 & 0.301 \\
\hline $\mathrm{F}(3,392)$ instruments jointly equal 0 & & 5.59 & 3.58 & 5.76 & 6.56 \\
\hline Prob $>$ F & & 0.0009 & 0.014 & 0.0007 & 0.0002 \\
\hline
\end{tabular}

Village fixed effects implemented

County * Marriage Cohort interactions included

Absolute value of $t$ statistics in parentheses

$*$ significant at $10 \%$; ** significant at $5 \%$; *** significant at $1 \%$ 
Table 1B: Determinants of Brideprice (OLS)

\begin{tabular}{|c|c|c|c|c|c|}
\hline Variable & Unit & $(1)$ & $(2)$ & (3) & $(4)$ \\
\hline grain shock 1 year before marriage & $\mathrm{kg} /$ person & $\begin{array}{l}1.883 \\
(1.43)\end{array}$ & $\begin{array}{l}2.118 \\
(1.63)\end{array}$ & $\begin{array}{l}2.115 \\
(1.60)\end{array}$ & $\begin{array}{l}2.042 \\
(1.57)\end{array}$ \\
\hline sex composition of wife's sibs & difference & $\begin{array}{l}33.233^{*} \\
(1.70)\end{array}$ & & & \\
\hline sex composition of husband's sibs & difference & $\begin{array}{l}22.322 \\
(1.37)\end{array}$ & & & \\
\hline sex comp of wife's older sibs & difference & & $\begin{array}{l}25.663 \\
(1.12)\end{array}$ & & \\
\hline sex comp of husband's older sibs & difference & & $\begin{array}{l}85.894 * * * \\
(3.92)\end{array}$ & & $\begin{array}{l}81.598 * * * \\
(3.74)\end{array}$ \\
\hline sex comp of wife's younger sibs & difference & & & $\begin{array}{l}25.548 \\
(0.98)\end{array}$ & $\begin{array}{l}16.223 \\
(0.63)\end{array}$ \\
\hline sex comp of husband's younger sibs & difference & & & $\begin{array}{l}-36.074 * \\
(1.67)\end{array}$ & \\
\hline age difference & years & $\begin{array}{l}-8.568 \\
(0.87)\end{array}$ & $\begin{array}{l}-9.220 \\
(0.96)\end{array}$ & $\begin{array}{l}-13.218 \\
(1.34)\end{array}$ & $\begin{array}{l}-9.542 \\
(0.99)\end{array}$ \\
\hline education difference & grades & $\begin{array}{l}12.569 \\
(1.50)\end{array}$ & $\begin{array}{l}10.377 \\
(1.25)\end{array}$ & $\begin{array}{l}14.454^{*} \\
(1.73)\end{array}$ & $\begin{array}{l}11.215 \\
(1.35)\end{array}$ \\
\hline children in home & \# & $\begin{array}{l}58.892 * \\
(1.90)\end{array}$ & $\begin{array}{l}58.406^{*} \\
(1.91)\end{array}$ & $\begin{array}{l}62.584 * * \\
(2.01)\end{array}$ & $\begin{array}{l}56.734^{*} \\
(1.85)\end{array}$ \\
\hline other adults in home & \# & $\begin{array}{l}-8.927 \\
(0.24)\end{array}$ & $\begin{array}{l}-10.471 \\
(0.29)\end{array}$ & $\begin{array}{l}0.326 \\
(0.01)\end{array}$ & $\begin{array}{l}-10.293 \\
(0.29)\end{array}$ \\
\hline wife's parents' ed & years & $\begin{array}{l}-16.087 \\
(0.74)\end{array}$ & $\begin{array}{l}-14.528 \\
(0.63)\end{array}$ & $\begin{array}{l}-6.331 \\
(0.71)\end{array}$ & $\begin{array}{l}-16.382 \\
(0.70)\end{array}$ \\
\hline husband's parents' ed & years & $\begin{array}{l}-16.407 \\
(0.70)\end{array}$ & $\begin{array}{l}0.043 \\
(0.00)\end{array}$ & $\begin{array}{l}-16.868 \\
(0.29)\end{array}$ & $\begin{array}{l}-6.433 \\
(0.30)\end{array}$ \\
\hline wife's total siblings & \# & $\begin{array}{l}5.852 \\
(0.32)\end{array}$ & $\begin{array}{l}-1.690 \\
(0.09)\end{array}$ & $\begin{array}{l}10.366 \\
(0.57)\end{array}$ & $\begin{array}{l}2.097 \\
(0.12)\end{array}$ \\
\hline husband's total siblings & \# & $\begin{array}{l}4.717 \\
(0.25)\end{array}$ & $\begin{array}{l}4.377 \\
(0.24)\end{array}$ & $\begin{array}{l}6.263 \\
(0.33)\end{array}$ & $\begin{array}{l}5.396 \\
(0.29)\end{array}$ \\
\hline Constant & & $\begin{array}{l}550.746^{* * *} \\
(3.90)\end{array}$ & $\begin{array}{l}574.593 * * * \\
(4.11)\end{array}$ & $\begin{array}{l}527.010^{* * * *} \\
(3.72)\end{array}$ & $\begin{array}{l}565.251 * * * \\
(4.04)\end{array}$ \\
\hline $\begin{array}{l}\text { Village FE } \\
\text { County FE }\end{array}$ & & yes & yes & yes & yes \\
\hline Observations & & 451 & 451 & 451 & 451 \\
\hline R-squared & & 0.426 & 0.441 & 0.424 & 0.440 \\
\hline $\mathrm{F}(3,392)$ instruments jointly equal 0 & & 2.51 & 6.05 & 2.00 & 5.74 \\
\hline Prob $>F$ & & 0.0583 & 0.0005 & 0.1141 & 0.0007 \\
\hline
\end{tabular}

Village fixed effects implemented

County * Marriage Cohort interactions included

Absolute value of $\mathrm{t}$ statistics in parentheses

* significant at $10 \% ; * *$ significant at $5 \% ; * * *$ significant at $1 \%$ 
Table 2. Variables and Summary Statistics

\begin{tabular}{|c|c|c|c|c|c|}
\hline Variable & Unit & Mean & $\begin{array}{l}\text { Std. } \\
\text { Dev. }\end{array}$ & Min & Max \\
\hline $\begin{array}{l}\text { wife's leisure (non-work) } \\
\text { time }\end{array}$ & hours per day & 19.02 & 2.57 & 11.51 & 24 \\
\hline $\begin{array}{l}\text { wife's share of couple's } \\
\text { total leisure (non-work) } \\
\text { time }\end{array}$ & $\%$ of couple's total leisure time & $48.00 \%$ & $3.82 \%$ & $33.02 \%$ & $58.34 \%$ \\
\hline $\begin{array}{l}\text { husband's time allocated to } \\
\text { chores }\end{array}$ & hours per week & 0.74 & 1.41 & 0 & 15 \\
\hline $\begin{array}{l}\text { husband's share of couple's } \\
\text { time allocated to chores }\end{array}$ & $\%$ of couple's total time devoted to chores & $17.73 \%$ & $27.13 \%$ & $0 \%$ & $100 \%$ \\
\hline $\begin{array}{l}\text { share of household } \\
\text { spending accruing to } \\
\text { women's goods }\end{array}$ & $\%$ of annual household spending & $0.19 \%$ & $0.38 \%$ & $0 \%$ & $2.01 \%$ \\
\hline wife's satisfaction & $\begin{array}{l}1=\text { completely unsatisfied, } 2=\text { somewhat } \\
\text { unsatisfied, } 3=\text { somewhat satisfied, } 4= \\
\text { completely satisfied }\end{array}$ & 2.60 & 0.57 & 1 & 4 \\
\hline $\begin{array}{l}\text { wife's decision-making } \\
\text { authority }\end{array}$ & $\begin{array}{l}0=\text { husband makes decisions, } 0.5=\text { both } \\
\text { make decisions, } 1=\text { wife makes decisions }\end{array}$ & 0.35 & 0.43 & 0 & 1 \\
\hline dowry & yuan, 1985 real value & 247.12 & 313.79 & 0 & 2044 \\
\hline brideprice & yuan, 1985 real value & 537.89 & 748.19 & 0 & 7493 \\
\hline wealth & value of durables, 1985 real yuan & 653.90 & 806.29 & 0 & 7297 \\
\hline length of marriage & years & 19.38 & 10.80 & 1 & 51 \\
\hline husband's age & years & 43.18 & 10.79 & 23 & 74 \\
\hline wife's age & years & 40.45 & 10.38 & 21 & 70 \\
\hline age difference & husband's age - wife's age & 2.73 & 3.24 & -7 & 16 \\
\hline husband's education & grades completed & 6.14 & 3.80 & 0 & 16 \\
\hline wife's education & grades completed & 2.90 & 3.47 & 0 & 14 \\
\hline education difference & husband's ed - wife's ed & 3.24 & 3.75 & -12 & 12 \\
\hline children in home & \# & 1.43 & 1.14 & 0 & 5 \\
\hline other adults in home & \# & 0.64 & 0.91 & 0 & 4 \\
\hline wife's parents' education & total years & 2.38 & 4.01 & 0 & 24 \\
\hline husband's parents' ed & total years & 2.36 & 3.70 & 0 & 24 \\
\hline wife's total siblings & \# & 3.84 & 1.74 & 0 & 11 \\
\hline husband's total siblings & \# & 3.70 & 1.74 & 0 & 8 \\
\hline Sichuan & province dummy & 0.24 & 0.43 & & \\
\hline Guizhou & province dummy & 0.30 & 0.46 & & \\
\hline Shaanxi & province dummy & 0.23 & 0.42 & & \\
\hline Gansu & province dummy & 0.23 & 0.42 & & \\
\hline $\begin{array}{l}\text { grain shock } 1 \text { year before } \\
\text { marriage }\end{array}$ & deviation from time trend, in $\mathrm{kg} /$ person & -1.65 & 27.86 & -90.82 & 64.01 \\
\hline $\begin{array}{l}\text { wife's sibling sex } \\
\text { composition }\end{array}$ & $\begin{array}{l}\text { difference in \#s of younger sisters and } \\
\text { brothers }\end{array}$ & -0.21 & 1.38 & -4 & 4 \\
\hline $\begin{array}{l}\text { husband's sibling sex } \\
\text { composition }\end{array}$ & difference in \#s of older sisters and brothers & 0.11 & 1.41 & -6 & 6 \\
\hline
\end{tabular}




\section{Table 3. Non-Instrumented Estimates (OLS and Probit)}

1: wife's leisure (non-work) time (OLS)

2: husband's time allocated to chores (OLS)

3: share of household spending accruing to women's goods (OLS)

4: wife's satisfaction (probit)

5: wife's decision-making authority (ordered probit)

\begin{tabular}{|c|c|c|c|c|c|c|}
\hline Variable & Unit & $(1)$ & $(2)$ & (3) & $(4)$ & $(5)$ \\
\hline \multirow[t]{2}{*}{ dowry } & 100 & $0.10376^{* *}$ & -0.01172 & $0.00024 * * *$ & $0.08851 * * *$ & 0.02234 \\
\hline & & $(2.24)$ & $(0.43)$ & $(3.46)$ & (5.59) & $(1.30)$ \\
\hline \multirow[t]{2}{*}{ brideprice } & $\begin{array}{l}100 \\
\text { yuan }\end{array}$ & -0.02539 & -0.01144 & $-0.00007 * *$ & 0.00263 & 0.01352 \\
\hline & & $(1.16)$ & $(0.90)$ & $(2.32)$ & $(0.43)$ & $(1.50)$ \\
\hline age difference & years & $\begin{array}{l}-0.08083 * * \\
(2.11)\end{array}$ & $\begin{array}{l}0.02182 \\
(0.98)\end{array}$ & $\begin{array}{l}-0.00000 \\
(0.05)\end{array}$ & $\begin{array}{l}-0.00227 \\
(0.23)\end{array}$ & $\begin{array}{l}0.00056 \\
(0.03)\end{array}$ \\
\hline education difference & grades & $\begin{array}{l}-0.03858 \\
(1.18)\end{array}$ & $\begin{array}{l}0.01324 \\
(0.69)\end{array}$ & $\begin{array}{l}-0.00006 \\
(1.32)\end{array}$ & $\begin{array}{l}-0.01546^{*} \\
(1.70)\end{array}$ & $\begin{array}{l}0.00368 \\
(0.24)\end{array}$ \\
\hline children in home & \# & $\begin{array}{l}0.07411 \\
(0.61)\end{array}$ & $\begin{array}{l}0.02665 \\
(0.38)\end{array}$ & $\begin{array}{l}-0.00025 \\
(1.44)\end{array}$ & $\begin{array}{l}0.01530 \\
(0.45)\end{array}$ & $\begin{array}{l}-0.03103 \\
(0.38)\end{array}$ \\
\hline other adults in home & \# & $\begin{array}{l}0.14579 \\
(1.03)\end{array}$ & $\begin{array}{l}-0.11921 \\
(1.44)\end{array}$ & $\begin{array}{l}0.00048 * * \\
(2.29)\end{array}$ & $\begin{array}{l}0.09041 * * * \\
(2.63)\end{array}$ & $\begin{array}{l}0.11499 \\
(1.53)\end{array}$ \\
\hline wife's parents' ed & years & $\begin{array}{l}0.06429 \\
(0.83)\end{array}$ & $\begin{array}{l}0.11730 * * * \\
(2.61)\end{array}$ & $\begin{array}{l}0.00003 \\
(0.26)\end{array}$ & $\begin{array}{l}-0.01893 \\
(1.10)\end{array}$ & $\begin{array}{l}0.02796 \\
(1.00)\end{array}$ \\
\hline \multirow[t]{2}{*}{$\begin{array}{l}\text { husband's parents' } \\
\text { ed }\end{array}$} & years & 0.02941 & 0.02935 & 0.00011 & 0.01853 & $0.05837 * *$ \\
\hline & & $(0.32)$ & $(0.55)$ & $(0.85)$ & $(0.89)$ & (2.14) \\
\hline wife's total siblings & \# & $\begin{array}{l}0.00742 \\
(0.10)\end{array}$ & $\begin{array}{l}0.09580 * * \\
(2.31)\end{array}$ & $\begin{array}{l}-0.00002 \\
(0.17)\end{array}$ & $\begin{array}{l}-0.00952 \\
(0.46)\end{array}$ & $\begin{array}{l}0.01449 \\
(0.49)\end{array}$ \\
\hline husband's total sibs & \# & $\begin{array}{l}-0.06223 \\
(0.85)\end{array}$ & $\begin{array}{l}0.01293 \\
(0.30)\end{array}$ & $\begin{array}{l}-0.00007 \\
(0.62)\end{array}$ & $\begin{array}{l}0.01569 \\
(0.82)\end{array}$ & $\begin{array}{l}0.07524 * * \\
(2.08)\end{array}$ \\
\hline Constant & & $\begin{array}{l}20.31254^{* * * *} \\
(15.49)\end{array}$ & $\begin{array}{l}0.28503 \\
(0.37)\end{array}$ & $\begin{array}{l}0.00126 \\
(0.65)\end{array}$ & & \\
\hline Village FE & & yes & yes & yes & & \\
\hline County FE & & & & & yes & yes \\
\hline Observations & & 451 & 451 & 451 & 290 & 284 \\
\hline R-squared & & 0.255 & 0.155 & 0.283 & & \\
\hline
\end{tabular}

County * Marriage Cohort interactions included

Absolute value of robust $t$ or $\mathrm{z}$ statistics in parentheses

Errors are assumed to be clustered by village when county fixed effects are implemented

$*$ significant at $10 \% ; * *$ significant at $5 \% ; * * *$ significant at $1 \%$ 
Table 4. Wife's Time Allocation (IV OLS)

1: wife's daily leisure (non-work) time

2: wife's share of couple's total daily leisure (non-work) time

\begin{tabular}{|c|c|c|c|}
\hline Variable & Unit & $(1)$ & (2) \\
\hline dowry & 100 yuan & $\begin{array}{l}0.74092 * * \\
(2.22)\end{array}$ & $\begin{array}{l}0.00772 * \\
(1.75)\end{array}$ \\
\hline brideprice & 100 yuan & $\begin{array}{l}-0.27232 \\
(1.63)\end{array}$ & $\begin{array}{l}-0.00208 \\
(0.94)\end{array}$ \\
\hline age difference & years & $\begin{array}{l}-0.05477 \\
(1.06)\end{array}$ & $\begin{array}{l}-0.00025 \\
(0.36)\end{array}$ \\
\hline education difference & grades & $\begin{array}{l}0.01607 \\
(0.31)\end{array}$ & $\begin{array}{l}0.00032 \\
(0.47)\end{array}$ \\
\hline children in home & \# & $\begin{array}{l}-0.00887 \\
(0.05)\end{array}$ & $\begin{array}{l}-0.00051 \\
(0.21)\end{array}$ \\
\hline other adults in home & \# & $\begin{array}{l}0.13337 \\
(0.75)\end{array}$ & $\begin{array}{l}-0.00063 \\
(0.27)\end{array}$ \\
\hline wife's parents' ed & years & $\begin{array}{l}-0.04456 \\
(0.40)\end{array}$ & $\begin{array}{l}-0.00049 \\
(0.33)\end{array}$ \\
\hline husband's parents' ed & years & $\begin{array}{l}-0.14026 \\
(0.97)\end{array}$ & $\begin{array}{l}-0.00205 \\
(1.07)\end{array}$ \\
\hline wife's total siblings & \# & $\begin{array}{l}0.01996 \\
(0.22)\end{array}$ & $\begin{array}{l}-0.00026 \\
(0.22)\end{array}$ \\
\hline husband's total siblings & \# & $\begin{array}{l}-0.07392 \\
(0.80)\end{array}$ & $\begin{array}{l}-0.00070 \\
(0.58)\end{array}$ \\
\hline Constant & & $\begin{array}{l}17.60930^{* * *} \\
(9.13)\end{array}$ & $\begin{array}{l}0.44572 * * * \\
(17.44)\end{array}$ \\
\hline $\begin{array}{l}\text { Village FE } \\
\text { County FE }\end{array}$ & & yes & yes \\
\hline Observations & & 451 & 451 \\
\hline
\end{tabular}

County * Marriage Cohort interactions included

Absolute value of $t$ statistics in parentheses

$*$ significant at 10\%; ** significant at 5\%; *** significant at $1 \%$ 


\section{Table 5. Husband's Time Allocation (IV OLS)}

1: husband's weekly time allocated to chores

2: husband's share of couple's total weekly time allocated to chores

\begin{tabular}{llll}
\hline Variable & Unit & \multicolumn{1}{c}{$(1)$} & \multicolumn{1}{c}{$(2)$} \\
\hline \multirow{2}{*}{ dowry } & \multirow{2}{*}{100 yuan } & $0.47691^{* *}$ & $0.11173^{* *}$ \\
& & $(2.27)$ & $(2.41)$ \\
brideprice & \multirow{2}{*}{100 yuan } & -0.11662 & -0.02934 \\
& & $(1.11)$ & $(1.27)$ \\
age difference & years & 0.05154 & $0.01309^{*}$ \\
& & $(1.58)$ & $(1.82)$ \\
education difference & grades & 0.04329 & 0.01053 \\
& & $(1.33)$ & $(1.47)$ \\
children in home & $\#$ & -0.09568 & -0.02296 \\
& & $(0.85)$ & $(0.92)$ \\
other adults in home & $\#$ & -0.12680 & -0.01503 \\
& & $(1.13)$ & $(0.61)$ \\
wife's parents' ed & years & 0.03348 & -0.01909 \\
& & $(0.48)$ & $(1.23)$ \\
husband's parents' ed & years & -0.09314 & -0.02024 \\
& & $(1.03)$ & $(1.01)$ \\
wife's total siblings & $\#$ & $0.09908^{*}$ & 0.01403 \\
& & $(1.75)$ & $(1.13)$ \\
husband's total siblings & $\#$ & -0.00180 & -0.01509 \\
& & $(0.03)$ & $(1.18)$ \\
Constant & & -1.46965 & -0.27327 \\
& & $(1.21)$ & $(1.02)$ \\
\hline Village FE & & yes & yes \\
County FE & & & \\
Observations & & 451 & 451 \\
\hline County & & &
\end{tabular}

County * Marriage Cohort interactions included Absolute value of $t$ statistics in parentheses

$*$ significant at $10 \% ; * *$ significant at $5 \% ; * * *$ significant at $1 \%$ 
Table 6. Share of Household Spending Accruing to Women's Goods (IV OLS)

\begin{tabular}{|c|c|c|c|}
\hline Variable & Unit & $(1)$ & (2) \\
\hline dowry & 100 yuan & $\begin{array}{l}0.00081 * \\
(1.85)\end{array}$ & $\begin{array}{l}0.00074 * \\
(1.67)\end{array}$ \\
\hline brideprice & 100 yuan & $\begin{array}{l}-0.00035 \\
(1.60)\end{array}$ & $\begin{array}{l}-0.00034 \\
(1.56)\end{array}$ \\
\hline age difference & years & $\begin{array}{l}0.00001 \\
(0.21)\end{array}$ & $\begin{array}{l}0.00003 \\
(0.38)\end{array}$ \\
\hline education difference & grades & $\begin{array}{l}-0.00001 \\
(0.10)\end{array}$ & $\begin{array}{l}-0.00000 \\
(0.05)\end{array}$ \\
\hline children in home & \# & $\begin{array}{l}-0.00029 \\
(1.24)\end{array}$ & $\begin{array}{l}-0.00028 \\
(1.21)\end{array}$ \\
\hline other adults in home & \# & $\begin{array}{l}0.00046^{* *} \\
(1.98)\end{array}$ & $\begin{array}{l}0.00035 \\
(0.89)\end{array}$ \\
\hline wife's parents' ed & years & $\begin{array}{l}-0.00007 \\
(0.47)\end{array}$ & $\begin{array}{l}-0.00009 \\
(0.55)\end{array}$ \\
\hline husband's parents' ed & years & $\begin{array}{l}-0.00004 \\
(0.23)\end{array}$ & $\begin{array}{l}-0.00007 \\
(0.33)\end{array}$ \\
\hline wife's total siblings & \# & $\begin{array}{l}-0.00000 \\
(0.02)\end{array}$ & $\begin{array}{l}-0.00001 \\
(0.07)\end{array}$ \\
\hline husband's total siblings & $\#$ & $\begin{array}{l}-0.00007 \\
(0.61)\end{array}$ & $\begin{array}{l}-0.00009 \\
(0.71)\end{array}$ \\
\hline household wealth & 100 yuan & & $\begin{array}{l}0.00002 \\
(0.38)\end{array}$ \\
\hline Constant & & $\begin{array}{l}-0.00154 \\
(0.61)\end{array}$ & $\begin{array}{l}-0.00175 \\
(0.66)\end{array}$ \\
\hline $\begin{array}{l}\text { Village FE } \\
\text { County FE }\end{array}$ & & yes & yes \\
\hline Observations & & 451 & 451 \\
\hline
\end{tabular}

County * Marriage Cohort interactions included

Absolute value of $\mathrm{t}$ statistics in parentheses

* significant at 10\%; ** significant at 5\%; *** significant at $1 \%$ 
Table 7. Wife's Satisfaction (IV Probit)

\begin{tabular}{|c|c|c|c|}
\hline Variable & Unit & (1) & $(2)$ \\
\hline dowry & 100 yuan & $\begin{array}{l}0.16087 * * \\
(2.23)\end{array}$ & $\begin{array}{l}0.12371 * \\
(1.73)\end{array}$ \\
\hline brideprice & 100 yuan & $\begin{array}{l}0.00823 \\
(0.26)\end{array}$ & $\begin{array}{l}0.01649 \\
(0.48)\end{array}$ \\
\hline age difference & years & $\begin{array}{l}0.00947 \\
(0.69)\end{array}$ & $\begin{array}{l}0.00896 \\
(0.66)\end{array}$ \\
\hline education difference & grades & $\begin{array}{l}-0.01546 \\
(1.44)\end{array}$ & $\begin{array}{l}-0.01420 \\
(1.25)\end{array}$ \\
\hline children in home & \# & $\begin{array}{l}-0.02719 \\
(0.53)\end{array}$ & $\begin{array}{l}-0.01917 \\
(0.39)\end{array}$ \\
\hline other adults in home & \# & $\begin{array}{l}0.09032 * * \\
(2.23)\end{array}$ & $\begin{array}{l}0.07068 \\
(1.29)\end{array}$ \\
\hline wife's parents' ed & years & $\begin{array}{l}-0.03548 \\
(1.35)\end{array}$ & $\begin{array}{l}-0.03355 \\
(1.29)\end{array}$ \\
\hline husband's parents' ed & years & $\begin{array}{l}-0.00195 \\
(0.06)\end{array}$ & $\begin{array}{l}0.00006 \\
(0.00)\end{array}$ \\
\hline wife's total siblings & \# & $\begin{array}{l}-0.00946 \\
(0.43)\end{array}$ & $\begin{array}{l}-0.01621 \\
(0.66)\end{array}$ \\
\hline husband's total siblings & \# & $\begin{array}{l}0.01521 \\
(0.70)\end{array}$ & $\begin{array}{l}0.01568 \\
(0.71)\end{array}$ \\
\hline household wealth, yuan & 100 yuan & & $\begin{array}{l}0.00531 \\
(0.58)\end{array}$ \\
\hline Village FE & & & \\
\hline $\begin{array}{l}\text { County FE } \\
\text { Observations }\end{array}$ & & $\begin{array}{l}\text { yes } \\
290\end{array}$ & $\begin{array}{l}\text { yes } \\
290\end{array}$ \\
\hline $\begin{array}{l}\text { Marginal effects shown } \\
\text { County * Marriage Coho } \\
\text { Absolute value of z stati } \\
* \text { significant at } 10 \% ; * *\end{array}$ & $\begin{array}{l}\text { t interacti } \\
\text { ics in par } \\
\text { gnificant }\end{array}$ & $\begin{array}{l}\text { Is included } \\
\text { theses } \\
5 \% \cdot * * * \text { si }\end{array}$ & cent \\
\hline
\end{tabular}


Table 8. Wife's Decision-Making Authority (IV Ordered Probit and IV Probit)

$1 \& 2:$ IV Ordered Probit Estimation

3 \& 4: IV Probit Estimation

\begin{tabular}{llllll}
\hline Variable & Unit & \multicolumn{1}{c}{$(1)$} & \multicolumn{1}{c}{$(2)$} & \multicolumn{1}{c}{$(3)$} & \multicolumn{1}{c}{$(4)$} \\
\hline dowry & 100 yuan & $0.40227^{* * *}$ & $0.41359^{* * *}$ & $0.15732^{* *}$ & $0.12514^{*}$ \\
& & $(2.55)$ & $(2.54)$ & $(2.03)$ & $(1.66)$ \\
brideprice & \multirow{2}{*}{100 yuan } & -0.09291 & -0.09850 & -0.03656 & -0.02666 \\
& & $(0.96)$ & $(0.99)$ & $(0.94)$ & $(0.69)$ \\
age difference & years & 0.02879 & 0.02466 & 0.01023 & 0.01078 \\
& & $(1.22)$ & $(0.95)$ & $(0.63)$ & $(0.70)$ \\
education difference & grades & 0.02467 & 0.02416 & 0.00930 & 0.01233 \\
& & $(1.56)$ & $(1.51)$ & $(0.73)$ & $(0.92)$ \\
children in home & $\#$ & -0.11180 & -0.10539 & -0.05196 & -0.04510 \\
& & $(1.23)$ & $(1.12)$ & $(0.92)$ & $(0.85)$ \\
other adults in home & $\#$ & 0.07585 & 0.10048 & 0.05779 & 0.02890 \\
& & $(1.02)$ & $(0.77)$ & $(1.22)$ & $(0.44)$ \\
wife's parents' ed & \multirow{2}{*}{ years } & -0.03288 & -0.02988 & -0.01948 & -0.02157 \\
& & $(0.82)$ & $(0.73)$ & $(0.73)$ & $(0.83)$ \\
husband's parents' ed & \multirow{2}{*}{ years } & -0.04052 & -0.03417 & -0.04121 & -0.04517 \\
& & $(1.14)$ & $(0.75)$ & $(1.25)$ & $(1.37)$ \\
wife's total siblings & $\#$ & 0.02638 & 0.02647 & 0.01525 & 0.00639 \\
& & $(0.81)$ & $(0.81)$ & $(0.59)$ & $(0.23)$ \\
husband's total siblings & $\#$ & 0.05520 & 0.05940 & 0.02624 & 0.02396 \\
& & $(1.39)$ & $(1.27)$ & $(1.04)$ & $(0.99)$ \\
wealth & \multirow{2}{*}{100 yuan } & & 0.00465 & & 0.00645 \\
& & & $(0.26)$ & & $(0.61)$ \\
\hline Village FE & & & & & \\
County FE & & yes & yes & yes & yes \\
Observations & & 293 & 293 & 284 & 284 \\
\hline
\end{tabular}

Marginal effects shown

County * Marriage Cohort interactions included

Absolute value of robust $\mathrm{z}$ statistics in parentheses

Standard errors are not corrected for IV ordered probit

* significant at $10 \%$; ** significant at $5 \%$; ** significant at $1 \%$ 


\section{DAVIDSON INSTITUTE WORKING PAPER SERIES - Most Recent Papers}

The entire Working Paper Series may be downloaded free of charge at: www.wdi.bus.umich.edu

CURRENT AS OF 9/8/03

\begin{tabular}{|c|c|c|}
\hline Publication & Authors & Date \\
\hline No. 608: Dowry and Intrahousehold Bargaining: Evidence from China & Philip H. Brown & Sept. 2003 \\
\hline $\begin{array}{l}\text { No. 607: Policy Regime Change and Corporate Credit in Bulgaria: } \\
\text { Asymmetric Supply and Demand Responses }\end{array}$ & $\begin{array}{l}\text { Rumen Dobrinsky and Nikola } \\
\text { Markov }\end{array}$ & Sept. 2003 \\
\hline $\begin{array}{l}\text { No. 606: Corporate Performance and Market Structure During } \\
\text { Transition in Hungary }\end{array}$ & László Halpern and Gábor Kõrösi & Aug. 2003 \\
\hline $\begin{array}{l}\text { No. 605: Culture Rules: The Foundations of the Rule of Law and Other } \\
\text { Norms of Governance }\end{array}$ & $\begin{array}{l}\text { Amir N. Licht, Chanan } \\
\text { Goldschmidt, and Shalom H. } \\
\text { Schwartz }\end{array}$ & Aug. 2003 \\
\hline No. 604: Institutional Subversion: Evidence from Russian Regions & $\begin{array}{l}\text { Irina Slinko, Evgeny Yakovlev, } \\
\text { and Ekaterina Zhuravskaya }\end{array}$ & Aug. 2003 \\
\hline $\begin{array}{l}\text { No. 603: The Effects of Privitzation and International Competitive } \\
\text { Pressure on Firms' Price-Cost Margins: Micro Evidence from Emerging } \\
\text { Economics }\end{array}$ & $\begin{array}{l}\text { Jozef Konings, Patrick Van } \\
\text { Cayseele and Frederic Warzynski }\end{array}$ & Aug. 2003 \\
\hline No. 602: The Usefulness of Corruptible Elections & $\begin{array}{l}\text { Loren Brandt and Matthew } \\
\text { Turner }\end{array}$ & Aug. 2003 \\
\hline No. 601: Banking Reform In Russia: A Window of Opportunity & Abdur Chowdhury & Aug. 2003 \\
\hline $\begin{array}{l}\text { No. 600: The Impact of Structural Reforms on Employment Growth and } \\
\text { Labour Productivity: Evidence from Bulgaria and Romania }\end{array}$ & Ralitza Dimova & Aug. 2003 \\
\hline $\begin{array}{l}\text { No. 599: Does Product Differentiation Explain The Increase in Exports } \\
\text { of Transition Countries? }\end{array}$ & Yener Kandogan & July 2003 \\
\hline $\begin{array}{l}\text { No. 598: Organizational Culture and Effectiveness: } \\
\text { Can American Theory Be Applied in Russia? }\end{array}$ & $\begin{array}{l}\text { Carl F. Fey and Daniel R. } \\
\text { Denison }\end{array}$ & July 2003 \\
\hline $\begin{array}{l}\text { No. 597: Asymmetric Fluctuation Bands in ERM and ERM-II: } \\
\text { Lessons from the Past and Future Challenges for EU Acceding } \\
\text { Countries }\end{array}$ & $\begin{array}{l}\text { Balázs Égert and Rafal } \\
\text { Kierzenkowski }\end{array}$ & July 2003 \\
\hline $\begin{array}{l}\text { No. 596: Mass Privatisation, Corporate Governance and Endogenous } \\
\text { Ownership Structure }\end{array}$ & Irena Grosfeld & July 2003 \\
\hline No. 595: WTO Accession: What's in it for Russia? & Abdur Chowdhury & July 2003 \\
\hline No. 594: The Political-Economy of Argentina's Debacle & Marcos A. Buscaglia & July 2003 \\
\hline $\begin{array}{l}\text { No. 593: While Labour Hoarding May Be Over, Insiders' Control Is } \\
\text { Not. Determinants of Employment Growth in Polish Large Firms, } \\
\text { 1996-2001 }\end{array}$ & $\begin{array}{l}\text { Kate Bishop and Tomasz } \\
\text { Mickiewicz }\end{array}$ & July 2003 \\
\hline $\begin{array}{l}\text { No. 592: Globalization and Trust: Theory and Evidence from } \\
\text { Cooperatives }\end{array}$ & $\begin{array}{l}\text { Ramon Casadesus-Masanell and } \\
\text { Tarun Khanna }\end{array}$ & June 2003 \\
\hline $\begin{array}{l}\text { No. 591: Restructuring or Disintegration of the German Corporate } \\
\text { Network: Globalization as a Fifth Column }\end{array}$ & Bruce Kogut and Gordon Walker & June 2003 \\
\hline $\begin{array}{l}\text { No. 590: Institutional Change and Firm Creation in East-Central } \\
\text { Europe: An Embedded Politics Approach }\end{array}$ & Gerald A. McDermott & June 2003 \\
\hline $\begin{array}{l}\text { No. 589: Legitimacy, Interest Group Pressure and Institutional Change: } \\
\text { The Case of Foreign Investment and Host Country Governments }\end{array}$ & $\begin{array}{l}\text { Witold J. Henisz and Bennet A. } \\
\text { Zelner }\end{array}$ & June 2003 \\
\hline $\begin{array}{l}\text { No. 588: Institutions and the Vicious Circle of Distrust in the Russian } \\
\text { Household Deposit Market, 1992-1999 }\end{array}$ & Andrew Spicer and William Pyle & June 2003 \\
\hline $\begin{array}{l}\text { No. 587: Foreign Direct Investment and the Business Environment in } \\
\text { Developing Countries: the Impact of Bilateral Investment Treaties }\end{array}$ & $\begin{array}{l}\text { Jennifer Tobin and Susan Rose- } \\
\text { Ackerman }\end{array}$ & June 2003 \\
\hline No. 586: Trust in China: A Cross-Regional Analysis & Rongzhu Ke and Weiying Zhang & June 2003 \\
\hline No. 585: Family Control and the Rent-Seeking Society & $\begin{array}{l}\text { Randall Morck and Bernard } \\
\text { Yeung }\end{array}$ & June 2003 \\
\hline $\begin{array}{l}\text { No. 584: Wage Determination: Privatised, New Private and State } \\
\text { Owned Companies, Empirical Evidence from Panel Data }\end{array}$ & $\begin{array}{l}\text { Tomasz Mickiewicz and Kate } \\
\text { Bishop }\end{array}$ & June 2003 \\
\hline No. 583: An Investigation of Firm-Level R\&D Capabilities in East Asia & $\begin{array}{l}\text { Gary H. Jefferson and Zhong } \\
\text { Kaifeng }\end{array}$ & June 2003 \\
\hline
\end{tabular}

